\title{
A MODIFIED METHOD OF CONDITIONED ORIENTATION REFLEX AUDIOMETRY
}

By

TETUYA TAKEI

\section{From the Department of Otolaryngology, Faculty of Medicine, Shinshu University, Matsumoto (Chief: Prof. T. Suzuki)}

Since the first report of conditioned orientation reflex audiometry (COR audiometry) by Suzuki and Ogiba, the reliability of the test has been examined from various aspects. However, the results obtained from the original procedure of COR audiometry was frequently found to be unreliable in children with asymmetric hearing losses including monaural deafness. The reasons for this unreliability of COR audiometry seem to lie in the facts that (1), for the children with asymmetric hearing losses or monaural deafness, the orientation to the direction of the sound stimulation is rather difficult and sometimes wholly impossible; (2) their heaing thresholds can vary according to the direction of the stimulus.

From these standpoints, a modified procedure of $\mathrm{COR}$ audiometry for children with asymmetric hearing losses was devised. In this method, sound stimulus and light stimulus were given separately. For example, sound stimulus was given from the right side and then the light stimulus was given from the left. Contrary to the generally accepted presumption, the response, that is head turning toward the source of the sound stimulus, was evoked distinctly and steadily even when the intensity of the sound stimuls was decreased near the threshold of the subjects. The light stimulus, in this case, may play the part of the supporter to the subject's attention toward the sound stimulus.

The application of this modified method to children with normal hearing revealed that the threshold values obtained from this modified method were almost the same as those obtained from the original method. As the modified method does not need the coincidental recognition of the direction of both sound and light stimlations, it is applicable to the children with asymmetric hearing losses or monaural deafness. The paper also covers the detailed description of the practice of this method to 12 cases with asymmetric hearing disorders. 


\section{条件詮索反射聴力測定法 (COR-audiometry) の改良に関する研究*}

信州大学医学部耳舅咽㘈科学教室（主任：鈴木篤郎教授）

武居哲管吊

第 1 編 COR-audiometry に扣ける方向音覚と音源の

方向による聴力の変動について

\section{第 1 算 緒}

play audiometry 仗先人により種々工夫されてきた

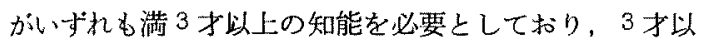
上の幻見の純音聴力測定は先分に可能であつても，3才 以下の乳纤児に対しては不確是か，又は全く不可能であ つた.

鈴木，荻場 1２２３４４5６６７８８（条件詮柔反射聴力測定 法 (以下単に COR-audiometry と称する) 艺考案して，

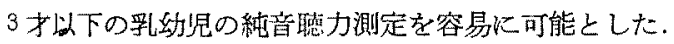
私9) も多数の聴力正常の 乳幼児に対する COR-audiometry を行いその成䋶を報告したが，本法の追武成維 はすでに Trenque et Lafon ${ }^{10)}$ (1961), Schröder u. Relkell) (1962) 等により発表されている.

始めに COR-audiometry の険査法について述べるこ とにする。湘定装置は第 1 図に示す如く極めて簡単で, 二つのスピーカーと二つの人形の入つた小部屋よりなつ ている，被検胃は多くの場合四親にだつこして蕒つて装 閣の㓩面約 $50 \mathrm{~cm}$ の所に坐らせる。ます $1000 \mathrm{cps}$ の純 袖から開始する。最初に被検児の閏值上 $40 \sim 50 \mathrm{db}$ と思 われる $1000 \mathrm{cps}$ の純音を左右いずれかー方のスピーカー より出し，それから約1秒遅れて同一方向の人形の電灯 をつけると，人形が美しく照明されて見えるので，被检 罗はそちら側へ顔を向けて注視する，中には音刺激だけ で振り向く者もあるが，その場合で当操作は同一てで良い。 率を4〜5秒，從つて照明を3〜4秘継絓したら両者を

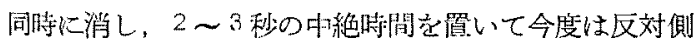

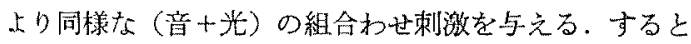
被検巟は反対侧を振り向きその方の人形を眺める。この

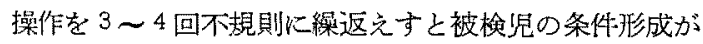
でき上り，今度は望刺激を与えただけで直りに聞えた方 向を振り向くようになる。

* 德器機能検查法研究 第 52 報
条件反射が充分形成された所で閶值の測定にらつる。 大休硧值に近いと思われる音の強さで（音+光）の組合 わせ刺激を一側上り与え，ついで 2 ○秒の間隔で，直 ちに反刘側入同じ強さの音のみを与えて振り向くかどう かを観察する。この際はつきりした反応があれば $5 \mathrm{db}$ ステップで音の㤝さを下げて一・側より (音+光) の組合

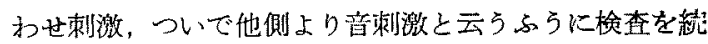
けて反応閶值を決定する。このよ5にして決定された反

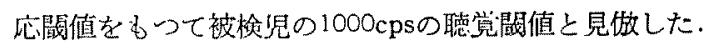
$1000 \mathrm{cps}$ の眽值が湘定されたら同様にして 2000,4000, $500 \mathrm{cps}$ の順に間值を测定するが，検查音の变るごとに $1 \sim 2$ 回間值上 40〜 50db と推定される音で（音+光） の強化刺激を与え，条件づけを強化しながら閶倠を測定 した。このよらにして得られた值は兩耳の綜合聴力であ Ђ.

以上述ベた COR-audiometry の央施に当つての一つ の問題は，本法の実施が難德児特に雨耳に聴力差のある 難德児に对しては正常児に対する場合のようには容易で なく，閾値の判定が困難時には不可能上なる昜合があ り，又その湘定值の信頼性にも疑問が生じうるという事 である.このことは我々が多数の難聴昌について本法を 司施している際常に感んしてきたことであり，又他の奏 施者より指摘乃至は質問されたこともある、本法の追試 成績を発表した前記 Trenque et Lafon 10)。「本法は 被検見の雨耳に著明な恥力差のある場合は過つた結果を もたら事がある」と述べている。いかなる原因により このような障書が生ずるのか，これを除去するにはいか にしたらよいのか，この点について检討を加えて見よら とするのが本研究の主なる目的である。

既に述べた如く，COR-audiometryには他の方法に は存在しない特異な点がある，それは㭘査音が方向のこ となる二つのスピーカーより出て、被検児は自由音場て これをきくと云らことと，判定の指標となる反応が，そ 
の音源の方を振り向くといら被检留の方向音覚を利用し た反応であるといら事である。従つて上述の障寒がこの ような検查法の特異性と結びついたるのであるであるう と云らことは容易に推察できる. 両耳に聴力差のある被 检览の場合，その方向音覚は不確実となり，当然音刺激

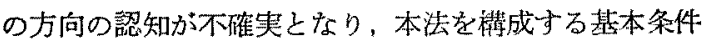
の一つである暗刺激方向と視覚刺激方向との結びつきが 失われてしまう。年の結果条件反射の形成そのるのが困 嚾となり，更䦪值測定段階において子振り向きが不明 膫となるものと思われる。

次に检查音の 音源に二つのスピーカーを用いること と，被検児が頭起自由の方向に動かしても良いことから くる問題である．例觉ば両耳に聴力差のある者の綜合闎 值を測定する場合に綜合閾値附近の音に対しては良耳側 のスピーカーよりの检查音は聞えてわ，同じ強さの悪耳 側のスピーカーよりの検查音以閏えないと云うことが起 りらる. 即ち二つのスピーカーのうちどちらを用いるか により又頭の方向により，同じ強さの检查音を与去てる 聞えたり開えなかつたりする場合が考劣られ，音の与兄

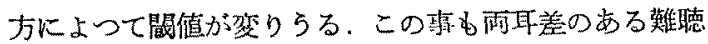
者に沶いて測定の困難をもたらす要因の一つになるので はないかと考光られる。

以上のような見地から，私は COR-audiometry 春施 時に和ける力向音賞と，音源の力向による聴力の変䡃が 两耳差のある難悖者においてどの程度であるかを微察

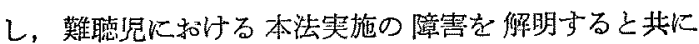
COR-audiometry の今後の改良海関す何等加の資料 を得よらと試みた。

\section{第 II 章 方向音覚}

(1) 测定方泣之测定刘象

第1図の如き COR-audiometry の溁蜀を用いて，被

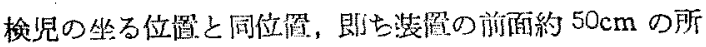
に正面に顔を向けさ圤たま专坐らせ，左と右のスピーカ 一より別々に检查音を $2 \sim 3$ 秒ずつ聞が退て，音が聞党 た場合左右のうらどりらの音源が指示させた，音が聞 えても音源の方向が不明の場合には不明上口答させた。

1）先ず㭘査音を被㭘者の良聴耳の閶値以下より音の 強さを任意に変化させつ左と右のスピーカーよりほぼ 交互に音を出して検查した。測定対象は成人の難聴者 25 名，正常者 15 名であり，そのらち難聴者 10 名, 正常者 5 名につき再検查をした。

2) 次㳊同じ強さの㭘查音を左右のスピーカーより不 㚘則酒続10回聴かせ，1回上り10回までの間にとの
第1图 COR 湘定装置と頭とり位䁌的関保 $\mathrm{H}$ : 頭 Sr.S1：右及び左スピーカー $\mathrm{Br} . \mathrm{Bl}$ 右及び左人形箱 $\mathrm{P}-\mathrm{P}^{\prime}: \quad 85 \mathrm{~cm}$

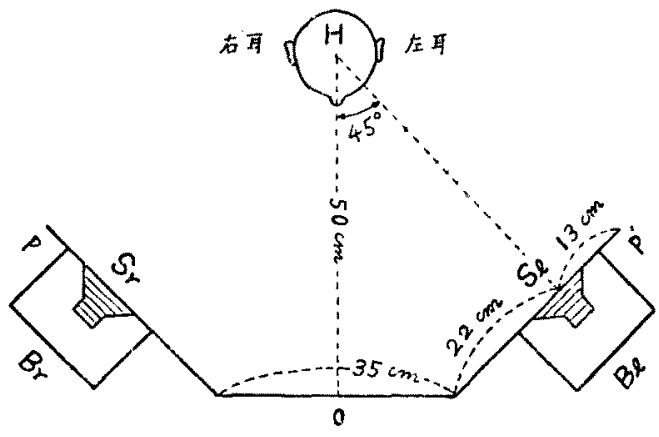

第 2 图筞 1 例

A：レシーパー式自觉閥䈍

\begin{tabular}{|c|c|c|c|}
\hline \multicolumn{2}{|c|}{$1000 \mathrm{cps}$} & \multicolumn{2}{|c|}{$4000 \mathrm{cps}$} \\
\hline 右 耳 & 左 耳 & 存 耳 & 在 耳 \\
\hline $70 \mathrm{lb}$ & 0 & 90 & 10 \\
\hline
\end{tabular}

B：方向音覚

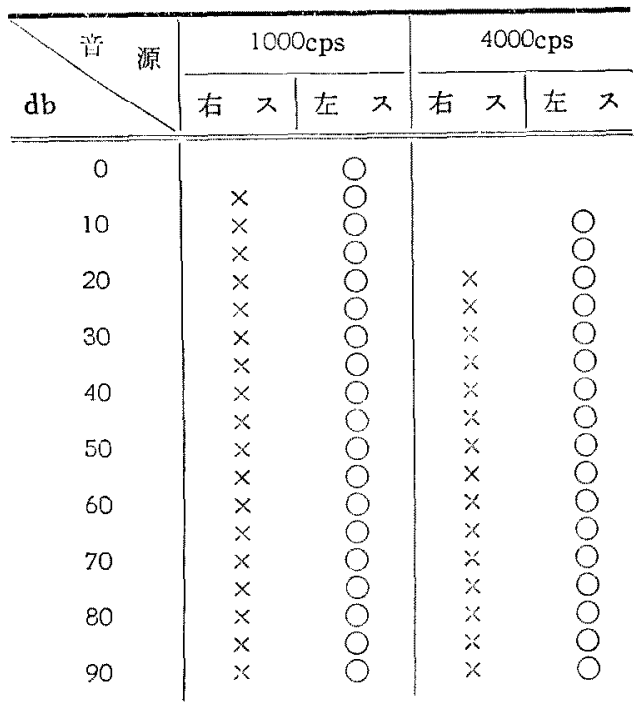

註：A：レシーバー式自喾閜値とは日常行ってい る standardaudiometry による閶做，Bの 「右ス」は音が右側スピーカーより出された場 合で○は音の与えられた侧に音源を認知した畦

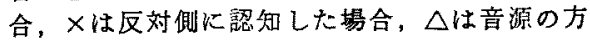
向不明の場合を指す. 以下同様. 


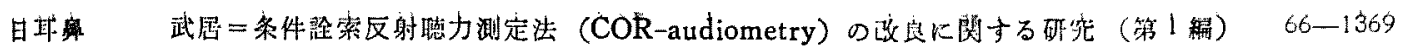

回数が增すにつれて認知の仕方が正確になつてくるかど らかを調べた，测定刘缘红成人の難㯖者 15 名，正常者 10 名である。

(2) 测定成結

洲定成績のらち代表的のもの10 例老第2 2 第 11 図に 示しておく。

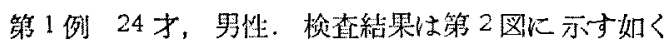
である．即ちこの被检者はすべての检查音に対して良耳 側のスビーカーより聞えてくるように認知する。

第 2 例 66 才，男性，検植結果は第 3 図に示方如く，

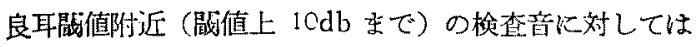
悪耳側のスピーカーより聞えるよらに認知するが，それ 以上のすべての検焦音に対しては第 1 例之同様良耳側の スピーカーより聞える上うに楒知する。綜合闌倠附近の 音が反刘側のスピーカー上り聞兑る上らに感じると云ら

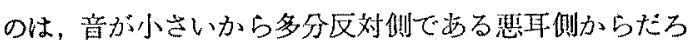
らと推測して応答したと被険者は検查後述へている．時 タこれと同じょうな例が認められた。

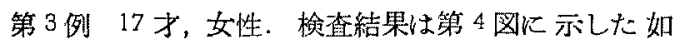

第 3 図第 2 例

A：レシーバー式自覚閶值

\begin{tabular}{cc|cc|cc|cc}
\hline \multicolumn{3}{c|}{$1000 \mathrm{cps}$} & \multicolumn{3}{|c}{$4000 \mathrm{cps}$} \\
\hline \hline 在 & 耳 & 左 & 耳 & 右 & 耳 & 左 & 耳 \\
$90^{\circ \mathrm{b}}$ & 以上 & & 10 & 90 以上 & \multicolumn{2}{|c|}{20}
\end{tabular}

B：方向穴觉

\begin{tabular}{|c|c|c|c|c|}
\hline \multirow{2}{*}{$\mathrm{db}$} & \multicolumn{2}{|c|}{$1000 \mathrm{cps}$} & \multicolumn{2}{|c|}{$4000 \mathrm{cps}$} \\
\hline & 存 ス & 左 $x$ & 在 & 左 $x$ \\
\hline 0 & & & & \\
\hline 10 & & $x$ & & \\
\hline & $\triangle$ & $x$ & & $x$ \\
\hline 20 & $\Delta$ & & & $\stackrel{x}{x}$ \\
\hline 30 & $\hat{x}$ & 0 & $\triangle$ & 0 \\
\hline & $x$ & 0 & $x$ & 0 \\
\hline 40 & $x$ & 0 & $x$ & 0 \\
\hline & $x$ & 0 & $x$ & 0 \\
\hline 50 & $x$ & 0 & $x$ & 0 \\
\hline & $x$ & 0 & $x$ & 0 \\
\hline 60 & $x$ & 0 & $x$ & 0 \\
\hline & x & 0 & $x$ & 0 \\
\hline 70 & $x$ & 0 & $x$ & 0 \\
\hline & $x$ & 0 & $x$ & 0 \\
\hline 80 & $x$ & 0 & $x$ & 0 \\
\hline & $x$ & 0 & $x$ & 8 \\
\hline 90 & $x$ & 0 & $x$ & 0 \\
\hline
\end{tabular}

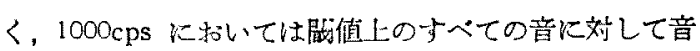

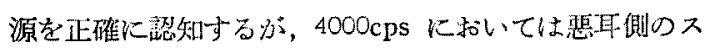
ピーカー上りの音に刘しては全く闒えず，良耳側よりの 音はその音源を正確に認知与る。

第4例 16 才，男性．再娭查例であり，検查結果は

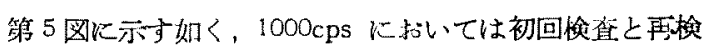
查はほぼ同じである。雨椧查とも良耳の闘值より $35 \mathrm{db}$ までは良耳側化音源があるよらに聞え，それ以上の音に 対しては音源の認知は正確である。

第 5 例 18 才, 男性. 再検查例であり，検查結果は

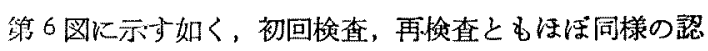
知の仕方をしている。即ち $1000 \mathrm{cps}$ に括いては良耳照值 より $15 \mathrm{db}$ 以上小での音は，ほぼ悪耳側のスピーカーよ り聞えるように証知するのに反し，それ以上の音は良耳 侧のスピーカー上り聞える様化認知与る。4000 cps に打 いては良耳闌値附近の穴に刘しては源の方向は不確害 であるが，それ以上の音に対してはほぼ正確に認知す る.

第6例 20 才，女性，再榆查例であり，検査結果は

第 4 図第 3 例

A：レシーバー式自覚閶值

\begin{tabular}{|c|c|c|c|}
\hline \multicolumn{2}{|c|}{$1000 \mathrm{cps}$} & \multicolumn{2}{|c|}{$4000 \mathrm{cps}$} \\
\hline $\begin{array}{c}\text { 右 耳 } \\
70^{\mathrm{db}}\end{array}$ & 左 ${ }_{80}^{\text {䎲 }}$ & $\begin{array}{l}\text { 石 耳 } \\
90 \text { 以上 }\end{array}$ & 左 ${ }_{80}^{耳}$ \\
\hline
\end{tabular}

B：方向觜觉

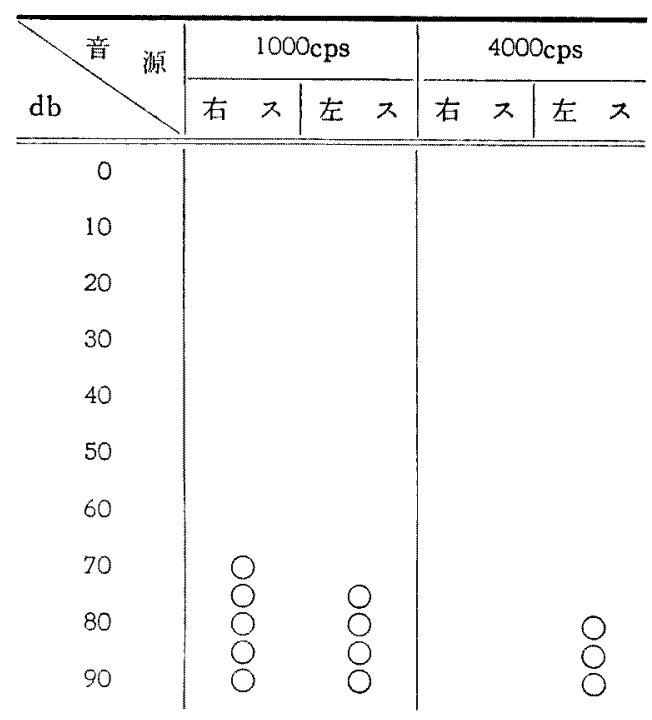


第7四に示寸如く，1000cps においては初回検查と再椧 查では全く逆である．即ち初回検查においてはすべての 音がたいたい右側のスピーカー上り聞えるように認知す るのに反し再検查では逆にすべての音が左側のスピーカ

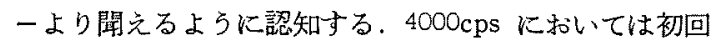
検査，再検查ともほぼ同様で，良耳側のスピーカーより の音汇対してはその音源を正しく認知するのに反し，悪 耳側のスピーカーよりの音に対しては不確实か双は良耳 側のスピーカーより聞えるように感しると云ら。

第 7 例 30 才，女性．連続换查の例である，検査結 果は第 8 図に示扣くで, $1000 \mathrm{cps}$ に如いては全般的に みて1回上り10回と回数が增すにつれて次第に音源の

第 5 図 第 4 例

A.レシーバー式自觉阙值

\begin{tabular}{|c|c|c|c|}
\hline \multicolumn{2}{|c|}{$1000 \mathrm{cps}$} & \multicolumn{2}{|c|}{$4000 \mathrm{cps}$} \\
\hline $\begin{array}{c}\text { 右 耳 } \\
15 \mathrm{db}\end{array}$ & 左 $\begin{array}{c}\text { 耳 } \\
-5\end{array}$ & 右 ${ }_{45}^{\text {咠 }}$ & t在 \\
\hline
\end{tabular}

B：方向音営

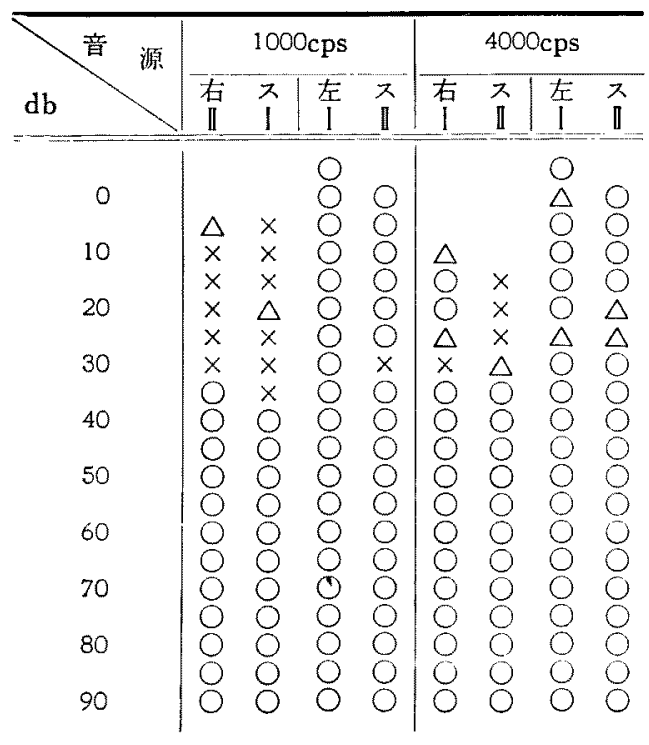

第 6 图第 5 例

A：レシーバ一式自覚閶值

\begin{tabular}{|c|c|c|c|}
\hline \multicolumn{2}{|c|}{$1000 \mathrm{cps}$} & \multicolumn{2}{|c|}{$4000 \mathrm{cps}$} \\
\hline 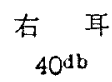 & 左 ${ }_{5}^{\text {耳 }}$ & 在 & $t_{10}$ \\
\hline
\end{tabular}

$\mathrm{B}$ ：方向音覚

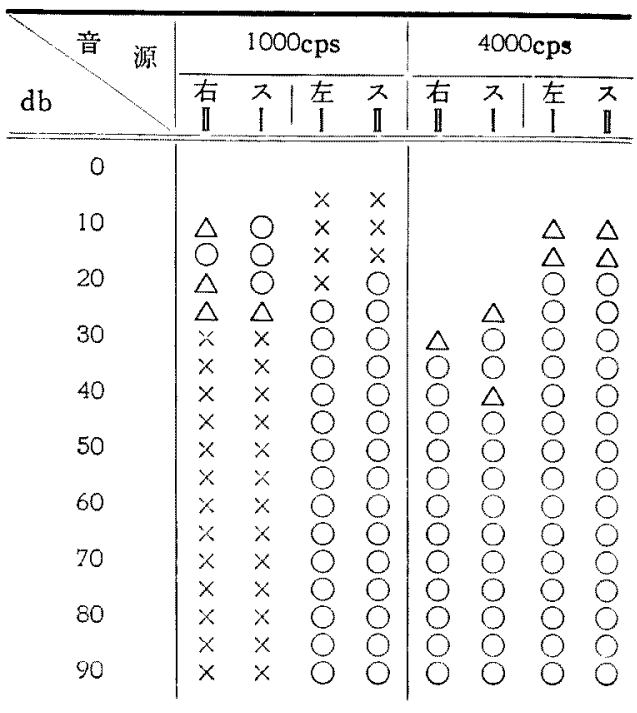

\begin{tabular}{|c|c|c|c|c|c|}
\hline & 100 & & & & cps \\
\hline $\begin{array}{c}\text { 存 耳 } \\
60 \mathrm{lb}\end{array}$ & & 左 $_{70}$ & 右 & $0^{耳}$ & 左 70 \\
\hline
\end{tabular}

B：方向音覚

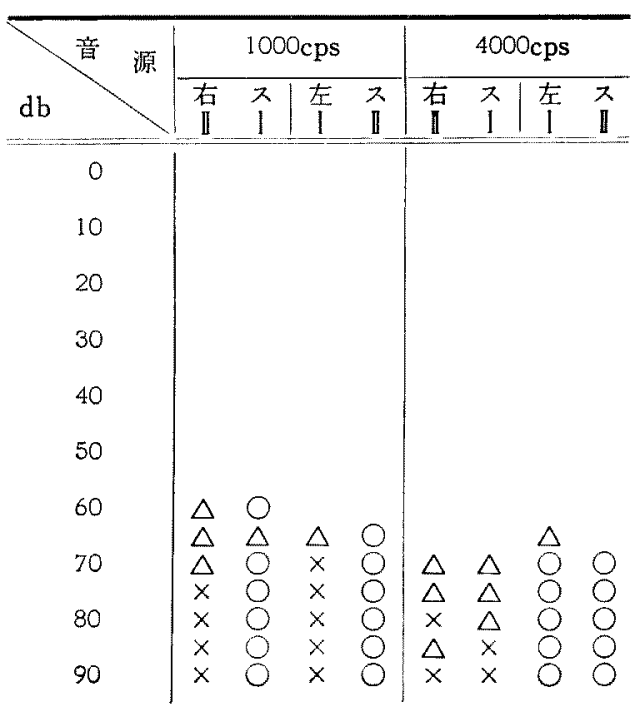




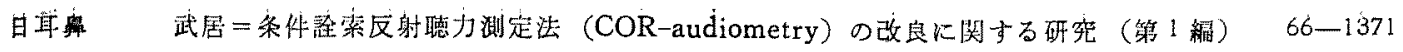

指南能力が正確になつてくるとは云えない.30db 以上 のすぺての筜に対して音源を正しく認知与る。30db以 下に特いては艮耳側のスピーカーよりの音はだいたい正。 しく認知寸るが琹耳側のスピーカー上りの音に対しては 音源を正しく認知できない $4000 \mathrm{cps}$ に打いても全般的 にみて $1000 \mathrm{cps}$ と同様回数が增すにつ机て正確になつて くるとは云兄ない． $25 \mathrm{db}$ 以上のすべての音に対しては 音源を正しく認知寸る。艺れ以下の歺べての音付対して は良耳侧晢源があるよう感じると云う。

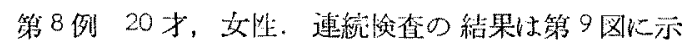
す如くで，1000 cps，4000 cps と屯全般的に回数が增すに

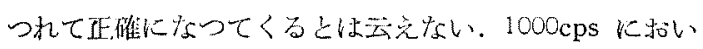

第 8 图 第 7 例

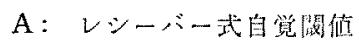

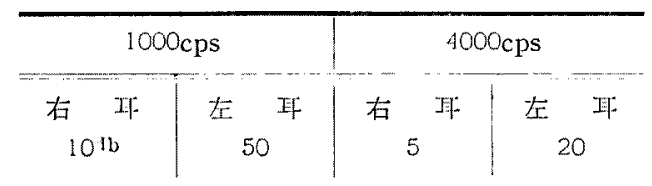

B：打向音覚 (1000cps)

\begin{tabular}{|c|c|c|c|c|c|c|c|c|c|c|}
\hline \multirow{2}{*}{$\mathrm{db} \underbrace{\frac{\text { 音 }}{\text { 源 }}}$} & 1 回 & 2 & 3 & 4 & 5 & 6 & 7 & 8 & 9 & 10 \\
\hline & 右 & 左 & 左 & 右 & 左 & 右 & 右 & 左 & 左 & 右 \\
\hline 15 & $\triangle$ & $x$ & $x$ & $x$ & $\Delta$ & 0 & 0 & $\triangle$ & $\triangle$ & 0 \\
\hline 20 & $\Delta$ & $x$ & $\triangle$ & 0 & $\triangle$ & $\triangle$ & 0 & $\Delta$ & $x$ & $\triangle$ \\
\hline 25 & 0 & 0 & 0 & 0 & $\triangle$ & 0 & 0 & $x$ & $x$ & $\triangle$ \\
\hline 30 & 0 & 0 & 0 & 0 & 0 & 0 & 0 & 0 & 0 & 0 \\
\hline
\end{tabular}

(4000 cps)

\begin{tabular}{|c|c|c|c|c|c|c|c|c|c|c|}
\hline \multirow{2}{*}{$\mathrm{db}$} & 1 国 & 2 & 3 & 4 & 5 & 6 & 7 & 8 & 9 & 10 \\
\hline & 右 & 在 & 左 & 右 & 左 & 右 & 右 & 左 & 左 & 右 \\
\hline 0 & $\Delta$ & & & $\Delta$ & & & $\triangle$ & & & \\
\hline 5 & 0 & $x$ & $\triangle$ & 0 & & 0 & 0 & & & 0 \\
\hline 10 & 0 & $x$ & $x$ & 0 & $x$ & 0 & 0 & $x$ & $x$ & 0 \\
\hline 20 & 0 & $x$ & $x$ & 0 & $x$ & 0 & 0 & $\times$ & $x$ & 0 \\
\hline 25 & 0 & 0 & 0 & 0 & 0 & 0 & 0 & 0 & 0 & 0 \\
\hline
\end{tabular}

第9図第 8 例

A. レシーバー式自敩閜值

\begin{tabular}{|c|c|c|c|}
\hline \multicolumn{2}{|c|}{$1000 \mathrm{cps}$} & \multicolumn{2}{|c|}{$4000 \mathrm{cps}$} \\
\hline $\begin{array}{c}\text { 右 耳 } \\
40^{1 \mathrm{~b}}\end{array}$ & 左 ${ }_{5}$ 耳 & 在 & 左 ${ }^{\text {F }}{ }^{\text {F }}$ \\
\hline
\end{tabular}

B：方向音覚 (1000 cps)

\begin{tabular}{|c|c|c|c|c|c|c|c|c|c|c|}
\hline \multirow{2}{*}{$\mathrm{db}$} & 1 国 & 2 & 3 & 4 & 5 & 6 & 7 & 8 & 9 & 10 \\
\hline & 右天 & 左 & 左 & 右 & 左 & 右 & 右 & 左 & 左 & 右 \\
\hline 5 & $\Delta$ & $x$ & $x$ & 0 & $x$ & $\Delta$ & $\triangle$ & $x$ & $\Delta$ & \\
\hline 10 & 0 & 0 & 0 & 0 & $\triangle$ & 0 & $\Delta$ & 0 & $\triangle$ & $\Delta$ \\
\hline 15 & $\Delta$ & $x$ & $x$ & 0 & $x$ & 0 & 0 & $\Delta$ & $\Delta$ & 0 \\
\hline 20 & 0 & 0 & $x$ & $\triangle$ & $x$ & 0 & 0 & 0 & $\Delta$ & 0 \\
\hline 25 & 0 & 0 & 0 & 0 & 0 & 0 & $x$ & 0 & 0 & $x$ \\
\hline 30 & 0 & 0 & 0 & 0 & 0 & 0 & 0 & 0 & 0 & 0 \\
\hline
\end{tabular}

$(4000 \mathrm{cps})$

\begin{tabular}{|c|c|c|c|c|c|c|c|c|c|c|}
\hline 篔 & 1 니 & 2 & 3 & 4 & 5 & 6 & 7 & 8 & 9 & 10 \\
\hline $\mathrm{db}$ & 右 & 左 & 左 & 右 & 左 & 右 & 右 & te & 左 & 右 \\
\hline 5 & & $x$ & & & $x$ & & & $\triangle$ & $x$ & \\
\hline 10 & & $x$ & $x$ & & $x$ & $\Delta$ & & $\Delta$ & $x$ & \\
\hline 15 & & $\times$ & $x$ & & $x$ & $\Delta$ & & $\Delta$ & $x$ & \\
\hline 20 & & 0 & 0 & 0 & 0 & & & 0 & 0 & \\
\hline 25 & 0 & 0 & 0 & 0 & 0 & $x$ & $x$ & 0 & 0 & $\Delta$ \\
\hline 30 & 0 & 0 & 0 & 0 & 0 & 0 & 0 & 0 & $x$ & 0 \\
\hline
\end{tabular}

第 10 图 第 9 例

A：レシーバー式自喾閵値

\begin{tabular}{|c|c|c|c|}
\hline \multicolumn{2}{|c|}{$1000 \mathrm{cps}$} & \multicolumn{2}{|c|}{$4000 \mathrm{cps}$} \\
\hline 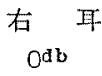 & 左 ${ }_{0}^{\text {耳 }}$ & 右 ${ }^{耳}$ & 左 ${ }^{\text {耳 }}$ \\
\hline
\end{tabular}

$\mathrm{B}$ ：方向音覚 (1000 cps)

\begin{tabular}{|c|c|c|c|c|c|c|c|c|c|c|}
\hline & 1 回 & 2 & 3 & 4 & 5 & 6 & 7 & 8 & 9 & 10 \\
\hline $\mathrm{db}$ & 右风 & 左 & tr & 右 & 左 & 右 & 右 & t & 左 & 右 \\
\hline 0 & 0 & 0 & 0 & 0 & 0 & 0 & 0 & 0 & 0 & 0 \\
\hline 5 & 0 & 0 & 0 & 0 & 0 & 0 & 0 & 0 & 0 & 0 \\
\hline 10 & 0 & 0 & 0 & 0 & 0 & 0 & 0 & 0 & 0 & 0 \\
\hline
\end{tabular}

(4000cps)

\begin{tabular}{|c|c|c|c|c|c|c|c|c|c|c|}
\hline \multirow{2}{*}{$\mathrm{db}$} & 1 回 & 2 & 3 & 4 & 5 & 6 & 7 & 8 & 9 & 10 \\
\hline & 右 & 左 & 左 & 右 & 左 & 右 & 右 & 左 & 左 & 右 \\
\hline-5 & & 0 & 0 & 0 & & & & & 0 & \\
\hline 0 & 0 & 0 & 0 & 0 & 0 & 0 & 0 & 0 & 0 & 0 \\
\hline 5 & 0 & 0 & 0 & 0 & 0 & 0 & 0 & 0 & 0 & 0 \\
\hline
\end{tabular}


第 11 图 第 10 例

A：レシーバー式自覚閔做

\begin{tabular}{|c|c|c|c|}
\hline \multicolumn{2}{|c|}{$1000 \mathrm{cps}$} & \multicolumn{2}{|c|}{$4000 \mathrm{cps}$} \\
\hline $\begin{array}{l}\text { 右 耳 } \\
-5 \mathrm{dh}\end{array}$ & $\begin{array}{c}\text { 在 } \\
-10\end{array}$ & 右 ${ }_{5}^{\text {耳 }}$ & 左 ${ }_{0}^{耳}$ \\
\hline
\end{tabular}

B：万问音覚 (1000 cps)

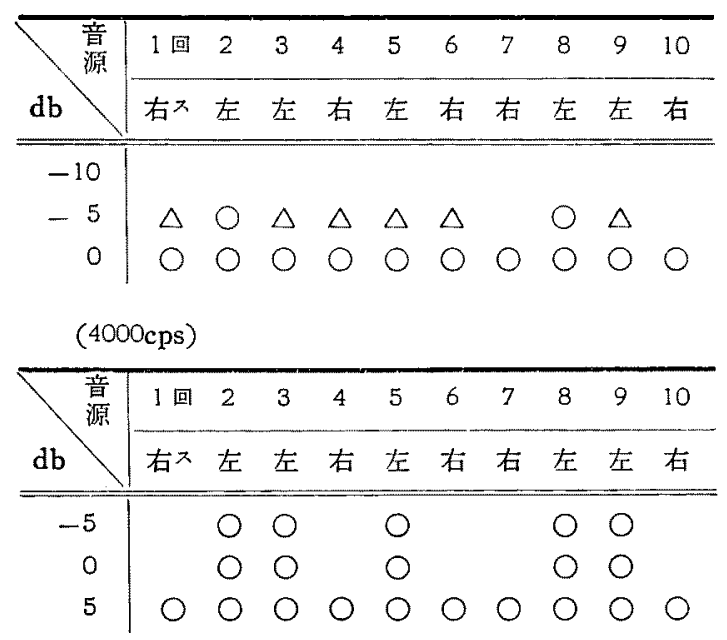

ては良耳の䦦值より $15 \mathrm{db}$ までは恶耳側に音源があるよ 万に聞える場合が多い，25db 以上の音に対してははぼ 昌源を正しく認知する．4000cps に括いては良耳の䦚值 より $10 \mathrm{db}$ までは悪耳側音源があるょうに聞える。 30db 以上の音に対しては音源をほぼ正しく認知する。

第 9 例 22 才，女性. 聴力正常の例である. 連緬検 查の結果は第 10 図炕示す如くで $1000 \mathrm{cps}, 4000 \mathrm{cps}$ 共聞 えるすべての音に効して音源への方向音覚は正確であ る.

第 10 例 16 才，男性. 聴力正常の例である. 連続検 查の結果は第11 图に示扣くで, $1000 \mathrm{cps}$ においては 右のスピーカーよりの $-5 \mathrm{db}$ の音に対しては，その音 源を正しく認知しない，4000 cps に括いては聞えるすべ ての音に対する音源えの方向音覚は正確である。

以上述べた10 例を含めて测定成績を綜括りると次の 如くになる.

1) 左右雨耳に聴力差のある場合には，良耳側のスピ 一カーよりの検查音に対しては音源を正しく認知する場 合が多い，しかし中には逆に閏值附近の音に対してたけ は恐耳側のスピーカーより聞えてくるよらに感じると云 う者む洔々ある。偠耳側のスピーカー上りの音に対して
は，悪耳關值以下の弱音に対しては良耳だけで閒くわけ であり，即ち一耳㯖となり音源の方向音覚は著しく悪

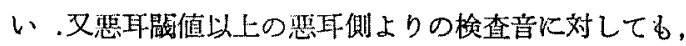
両耳聴となる稀けであるが，音源の認知は正確でない例 も多くみられた，又雨耳聴力差が大きくなるに往つて閶

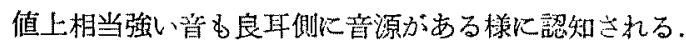

2）一側翼の場合には，良耳閶值附近の音を除外して すべての望が，一般に良耳侧のスピーカーより聞劣るよ うに認知する。

3）両側聴力正常者は，すべての音に対して正確に音 源を認知する。しかし左右雨汎 5〜10db の差がある

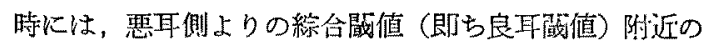
音に対しては音源を正しく認知しない㘷合も認められ 万.

4）两耳の聴力差唯 $10 \mathrm{db}$ 以内の難聴者の場合に心， 3）の場合と同粎のことが云えるが，惡耳侧よりの音に 対しては自筧闇值上 $30 \mathrm{db} て ゙$ 始らて力问を正しく認知し た例もあり，正常者に較べて相当惡い例もあると云兄 る.

5) 両耳差のある難缌者の力向音覚の初回検査と再検 查とを比較すると，両耳差が $20 〜 30 \mathrm{db}$ 以上の者では， 瑟耳側のスピーカーよりの音に対しては䦔值上 30〜50 $\mathrm{db}$ 位まで両检查成績が著明に異る場合が 3 例飞 1 例位 の割合で認められた。

6) 両耳盖のある難嚆者に同し強さの検查音を両スピ 一カー上り不規則に何回か聞かせても，音源の指南能力 が良くなつてくるよらな傾向な全く認められなかった。

(3).考按

方向音筧については古くから多くの研究がなされてい るが未だ充分に解明されていない点が多い大内等 ${ }^{12)}$

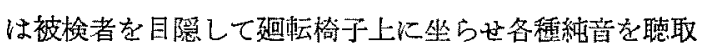
させて聞えたと思う音源の方何を指示せしめ，奏際代音 源のある方向との誤差争度を测定している. 正常者につ いては10名観察しているが正常者です音定位能力は予 想以上に粗雑であるが，音源が真横又は斜前力にある場 合に良好で 平均器差的度は $20^{\circ} \sim 30^{\circ}$ であつたと述べて いる. 片側難㯖者については 4 名漈察して, 難㯖耳侧に 音源がある場合には全例とも $80^{\circ}$ 以上の誤差を示したと 述べている．肥留川133 は半円状にまげた 鉄管の中心ル 被検者を坐らせ，スピーカーをこの鉄管上で移動させ て、䦨值上 $20 \mathrm{db}$ の純盲を閆かせて難聴者の力向音覚を 検查している，但し被検者の目を被う代りに鉄管半円内 側に等間隔に数字をかいた垂幕をめぐらしてスピーカー 


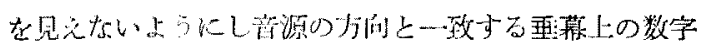

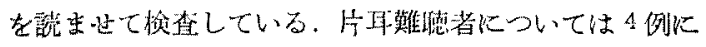
つき施行し，そのうち2 例は音源の指南能力は全く混乱 して拉り，1 例は患側よりの音源に対しては著しく誤差 が多つたが，1例は割合に誤差が少なかつたと報告して

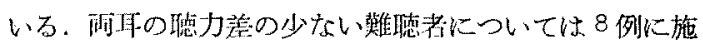

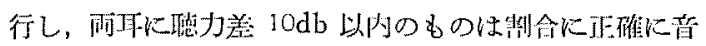

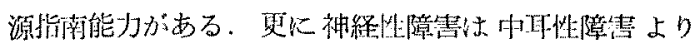

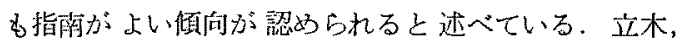

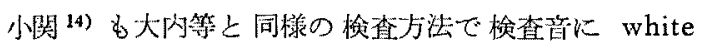
noise を用いて 5 名の正常聴力者と同じ被检者に一側外 耳道を指嘼を的つて密閉させて行つている. 正常埴力者 については後正面の封瑐と答劣ることは磨々あつたが 他万间は法ぼ正答した。しかし中には 450位の俱りを認 めるものるあつた，耳栓せる㘯合には耳检側よりの検査 音に対しては全く不定で，中梳すべての方向からの音 を開放㑬天り聞えると答克るむのもあつたと述べてい る.

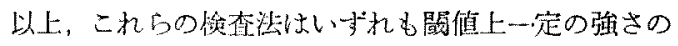

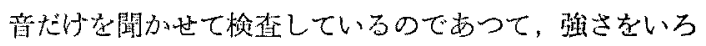
いろと变えてそれに応した方向音覚を梌查しているわけ ではない，従つて私の湘定成買と直接比校するわけには

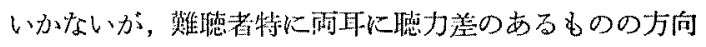
音觉山落しく刑いと云う点では法ぼ一致している。

万间筧觉の不確㞔な者に対与る COR-audiometryに いて考えて质ると，例壳ば第1例のような者について 云息ば，左右から音刺㦸を与克て子常に左方から聞えて くるように感ずるから，右方から（音十光）の組命わせ

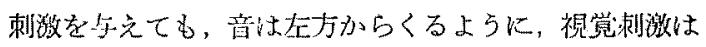

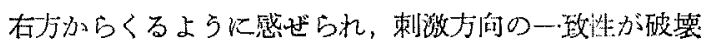
され，条件形成の段階で非常な国難に造遇与る，又第 4 例のさらな者について㕕总ば，間值上数 $10 \mathrm{db}$ の音に上

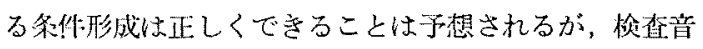
を弱如くる徒つて万向音覚がー方向に傾いたり双は 不確实になつており，正算奣の場合のような明睹な刺激 方向への振り向きは期待できないるのと思われる，從つ て，難聴児殊飞再耳に聴力差のある場合の COR-audiometry の㫪施の困難さの要因の一つとして，この力向 音覚の障慧が関与していることは間遥いないるのと見做 しうる.

更に，私の穓察は成人を対象に調べたのであるが，乳 奻児は成人上りも方向音觉が留いのではないかと教えら れる. Ewing ${ }^{15)}$ によれば生後 6 力月以前は音源に振り
向く能力は著しく覀く，振り向くにしても徐々であつた り，又数回音刺湤が操り返光された後であつたりする。 しかし次第に発達して 12 力月頃には著明に良くなると 述へている. 更に難㯖児については $2 \sim 3$ 才以前では著 しく覀く，2才前では1 回の音刺激で音源を認知するこ とは全く認められなかつたと述へている，從つて今回 の成人症例以見られたよらな方向音覚の障彗は COR一 audiometry の適応年令たる1〜3才㫕では更に落明に 出現しうるものと考えられる。

\section{第III 章 音源の方向による聴力の変動}

(1) 测定方法之測定対象

前述の測定方法之同粎に COR-audiometry の装揟を 用いて前面 $50 \mathrm{~cm}$ の所に正面に顔を向けさせたまま坐 ら世, 右のスピーカーと左のスピーカ一によりそれぞれ 被榆者の自覚法による阿耳綜合閾值を測定し，その测定 值問の差を述めた．1000 cps と $4000 \mathrm{cps}$ について求め た。

被検者は成人でレシーバ一式聴険による両耳閥值差 $20 \mathrm{db}$ 以上の雉㴔考 20 名，雨耳闌值差 $10 \mathrm{db}$ 以下の聴力 正常者 17 名である.

(2) 测定成繢

1) 雨耳閵佔差 $20 \mathrm{db}$ 以上の難聴者の測定成續は第 1 表に示す如くである. 即ち左右それぞれのスピーカーに 上る雨耳綜合聴力間倠の差惊 $\mathrm{Odb} 20 \mathrm{db}$ で，平均は $1000 \mathrm{cps}$ で $6.3 \mathrm{db}, 4000 \mathrm{cps}$ では $9.8 \mathrm{db}$ であつた.

2) 聴力正常者 17 名についての測定成績は第 2 表に 示す如くである．この成結と前揭第 1 表の成績との間に 有意差があるかどらかを統計学的に検討してみると， 1.0\%の危除率に打いて有意差があることが認められ る。

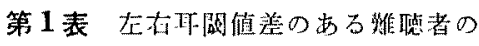
赫合閾值变軼 (20 例)

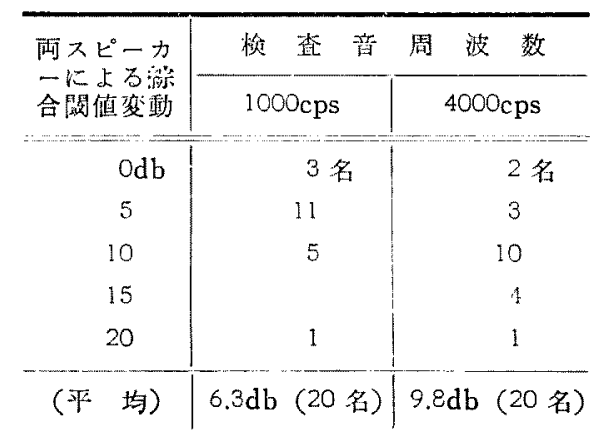




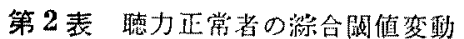
(17 例)

\begin{tabular}{|c|c|c|}
\hline \multirow{2}{*}{$\begin{array}{l}\text { 禹スピーカ } \\
\text { 一による沙 } \\
\text { 合閏值変動 }\end{array}$} & 蚞 查 音 & 波 \\
\hline & $1000 \mathrm{cps}$ & $4000 \mathrm{cps}$ \\
\hline 0 & 15 名 & 13 名 \\
\hline 5 & \multirow[t]{2}{*}{2} & 3 \\
\hline 10 & & 1 \\
\hline （平 均） & $0.6 \mathrm{db}(17$ 名) & $1.5 \mathrm{db}(17$ 名 $)$ \\
\hline
\end{tabular}

\section{(3) 考 按}

音源の力向に上る 聴力の变動に関し，村島 ${ }^{16)}$ は正常 者，一側性難聴者，両側性難㯖者の多数例について綿密 なる检查をして䇉告している，即ち，被检者の位咀はス

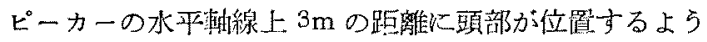
椅坐させ，音源に対して水平面で $30^{\circ}$ ずつ方向を变え， 1 周12万向での恥力閥值を $2 \mathrm{db}$ ステップで测定しだ。

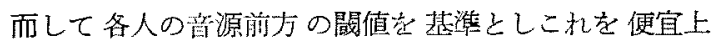

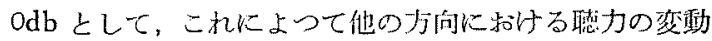

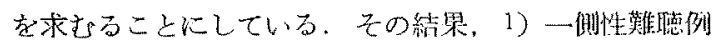

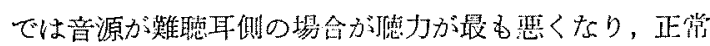
耳側の場合が最屯良くなる。2) 聴力正常例では音源が 側方の場合が聴力上乐する。3）丽側性難䏇例では雨耳

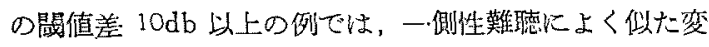
動がスられ，10db 以内の例で结，閔值差 $10 \mathrm{db}$ 以上の 例程には音源が悪耳側での䍜力低下は現れず，この関係

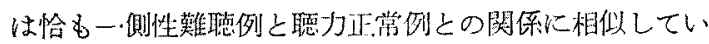
る、と結論を下している。

左右差つある難聴者の COR-audiometry の場合につ

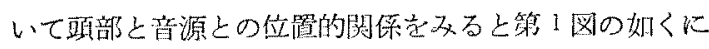
なり，角 OHSI は $45^{\circ}$ になるよらになつている.今仮 に被検者の左耳が難悖とし，右耳が正常とする．被検者 が SI の方向を向いているとすると，Sr は丁度正常耳 の前方になるるけである，徒つて Sr から检查音を用い

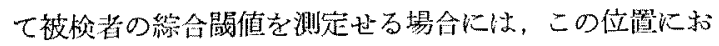
いてこの被榆者の聴力㵊も良くなることが河島の結論 上り云える，逝に被検者が Sr の方向を问いていたとす ると Sl 以難聴耳側になるかけであり，往つて被検者の 聴力は最毛瑟くなる。云易え机ば COR-audiometry に 小いては，二つのスピーカーのと゚ちらを用いるかにより 又頚の力向に上り，被检者の最も良く聞点る万问即ち良 耳側より榆查音を与えて綜合閥值を測定方る場合るある し，逝に最も聞点にくい力问即ち瑟耳侧より榆査音を与

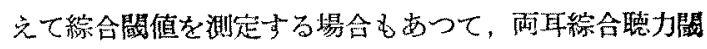
值にある蝠をもつたまちまちの值が出てくることにな る.

そこでこの幅について考えてみる、村島の諭文の一側 性菼隹㯖 (一側正常, 一側 $30 \mathrm{db}$ 以上の損失例) における 音源の方向による㴔力の変動の測定成績より音源が前 方，難聴耳侧，良耳侧にお多平均綜合闒值を取り出し

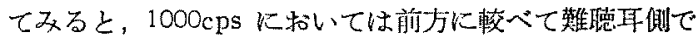
は顶均 $3.5 \mathrm{db}$ 瑟く，良耳侧で $2.4 \mathrm{db}$ 良くなり，その 幅は $5.9 \mathrm{db}$ である. $4000 \mathrm{cps}$ においては難聴耳側では $9.7 \mathrm{db}$ 墨く，良耳側では 2.cdb 既くなり，その幅は11.7 $\mathrm{db}$ である，1000 cps に較べて相当幅が大きくなる。 こ

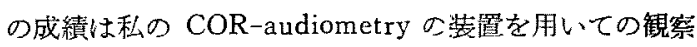

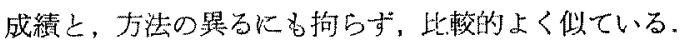
即ち雨耳差が $20 \mathrm{db}$ 以上ある者に対しては音の与方る側 によつて 5〜10db の閶值羔が出てくることが考学られ る.この数值杜測定成績を大さく左石する程のものでは

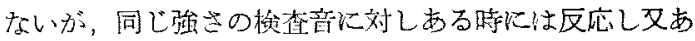

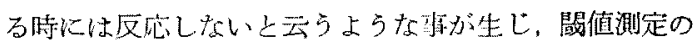

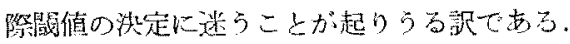

\section{第 IV 等 結語}

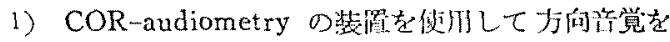
湘定した所，一般に唡耳差のある者の力向音覚は不睢害

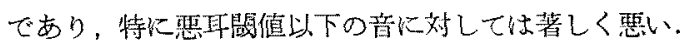
及個人盖車しい。

2) 従つて雨耳差のある者に対子る COR-audiome-

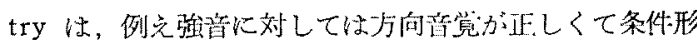

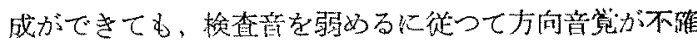

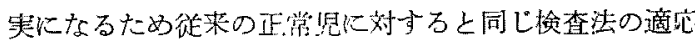
は国難か不可能となる，又始めから条留楼成ができない ことすある。このような場合には得られた測定值の信頼 性に疑問が持たれる。

3）COR-audiometry の泾籍走用いて正面を向いた

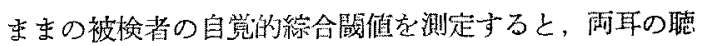
力善のある場介は二つのスピーカーのいられを用いるか

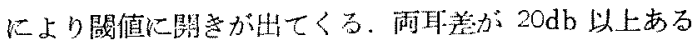
者では，1000cps で好平均 $6.3 \mathrm{db}, 4000 \mathrm{cps}$ では平均 9.8

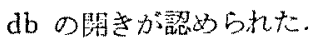

4) 従つて雨耳差つある者の COR-audiometry の場 合には，二つのスピーカーのどちらから音が出ているか

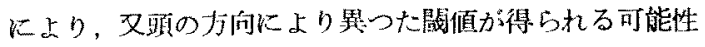
がある。 


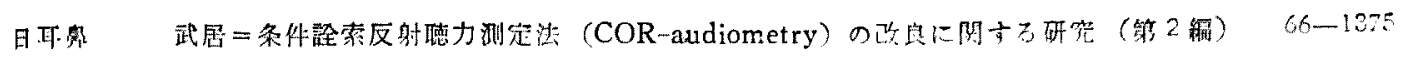

第 2 編 難聴胃のための COR-audiometry の 1 侧定法

(変法) について

\section{第 I章 緒 言}

私は第 1 編で特に両耳差のおる者に対する COR-audiometry には方向音覚障害や音源の方向に上る聴力の 変動特に前者が尔入して，充分な閶値測定が困難，又は 不可能になるであるらと述べた。この問題を解決するた めには，上述の障害が介入してもあまり影響のないよう な梌査法が要求される、私はこの点について工夫を試 み，従来報告された方法（原法）とは異る一つの測定法 を拷案した．この方法は原法とは原理的に異り、条佧 形成を必要としないのであるから，COR-audiometry と称することは適当でないのであるが，便宜上 CORaudiometry の変法と称しておく. そしてこの变法と原 法とを適当に組合わせて濑用することによつて，難㯖览 に対する COR-audiometry の適用をある程度容易にす ることができた。ここではむずこの測定法（変法）の基 濋となつた観察成績について述べ，それから本測定法と その応用について記载したい。

\section{第 II 章 基礎的観察}

(1) 钼察方法

COR-audiometry の蓝置を用いたが，小部屋の人形 が見えないように，あらかじめ小部屋の外に貼紙をして
打く，COR-audiometry の場合上同様に装置の前面約 $50 \mathrm{~cm}$ の所に被険贸を坐らせる. 左右のスピーカーより 结络交互に $1000 \mathrm{cps} 50 \mathrm{db}$ の束激音を与えて被检思の音 刺激への詮索反射（振り向き）の状態をみる，音刺激の 回数は左右合わせて10回である.

次に貼紙取り米刺激 (人形の照明) と50db の音刺 激とを各々独立に不规則に左右上り与之て，被㭥児の反 応状態老観察する。この場合原法とは全く異なり，光刺

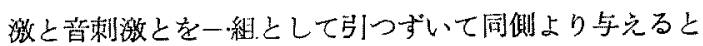
いらよらなことはしない，即ち，例之ばます音制湤のみ を右から与えたとすれば，音刺激を中比した後今度は米 刺激を戦独で左上り与えるといらようにする。刺激回数 は音刺激之光刺激を合わせて14 回〜20回でこの中音刺 激の回数は 10 回である.

(2) 観察成絰及び考㑕

本法の反応の強さを，

1. 即座に音源の方向向く(卅)

2. はつきりと音源の方向古向く(H)

3. のろいが音源の方向を向く（十）

4. 音源の力向を向かないが，眼を動かしたり，眼を すえて聞さ入る(土)

第 12 図音刺激之の反応の強さ

\begin{tabular}{|c|c|c|c|c|c|c|c|c|c|c|c|c|c|c|c|c|c|c|c|c|c|c|}
\hline \multirow{2}{*}{$\begin{array}{l}\text { 番 } \\
\text { 号 }\end{array}$} & \multirow{2}{*}{$\begin{array}{l}\text { 年 } \\
\text { 令 }\end{array}$} & \multirow{2}{*}{ 性 } & \multicolumn{10}{|c|}{ 音刺激だけの場合の反応の強さ } & \multicolumn{10}{|c|}{ 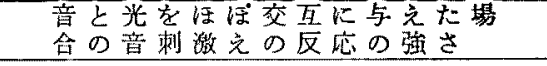 } \\
\hline & & & 1 回 & 2 & 3 & 4 & 5 & 6 & 7 & 8 & 9 & 10 & 1 回 & 2 & 3 & 4 & 5 & 6 & 7 & 8 & 9 & 10 \\
\hline 1 & $0: 12$ & ㅇ & $H$ & $H$ & + & + & + & + & + & - & + & - & $H$ & - & $\mathrm{HH}$ & $\mathrm{Ht}$ & $H$ & $H$ & H & $H$ & H & $\mathrm{Ht}$ \\
\hline 2 & $0: 12$ & $\delta$ & $H$ & \pm & + & + & - & - & \pm & - & \pm & - & H & $H$ & \pm & + & $H$ & + & \pm & + & $H$ & $H$ \\
\hline 3 & 1.3 & 욱 & H & $H$ & - & - & - & + & - & - & \pm & - & H & $\mathrm{HH}$ & $\mathrm{HH}$ & $H$ & \# & $\mathrm{Ht}$ & $H$ & + & $H$ & $H$ \\
\hline 4 & $1: 7$ & 8 & + & $H$ & $t+$ & + & + & + & + & - & \pm & - & - & $\mathrm{HH}$ & $\Delta$ & $H$ & $\mathrm{H}$ & $\mathrm{HH}$ & $\triangle$ & $H$ & $H$ & $\mathrm{HH}$ \\
\hline 5 & $2: 5$ & 우 & $\mathrm{HH}$ & $H$ & $H$ & - & - & $H$ & - & - & - & - & $H$ & HH & $\mathrm{HH}$ & H & $H$ & $H$ & H & $H$ & H & $\mathrm{Ht}$ \\
\hline 6 & $2: 8$ & $q$ & $\mathrm{HH}$ & - & $H$ & $H$ & - & $H$ & \pm & - & - & \pm & $\mathrm{HH}$ & $\triangle$ & $H$ & $H$ & H & $\mathrm{HH}$ & $\mathrm{HH}$ & $H$ & $\mathrm{HH}$ & $H$ \\
\hline 7 & $2: 11$ & $\delta$ & - & - & \pm & - & \pm & - & - & - & \pm & - & H & HI & $\mathrm{HH}$ & - & $H$ & + & $H$ & + & + & - \\
\hline 8 & $2: 11$ & $\delta$ & $H$ & + & - & - & + & $H$ & - & + & - & + & - & Ht & $\mathrm{HH}$ & $H$ & - & $H$ & \pm & $H$ & $H$ & \pm \\
\hline 9 & $2: 12$ & 우 & $\mathrm{HH}$ & $H H$ & + & + & - & + & - & + & \pm & - & $\mathrm{HH}$ & HH & $\mathrm{HH}$ & $\triangle$ & $H$ & + & $H$ & $H$ & $\mathrm{HH}$ & $H$ \\
\hline 10 & $3: 2$ & क & $H$ & $H$ & + & + & + & + & + & + & + & + & H & Ht & $\triangle$ & H & H & + & H & H & + & $H$ \\
\hline 11 & $3: 4$ & 8 & $H$ & $H$ & $H$ & $H$ & $H$ & + & $H$ & \pm & + & $+t$ & H & 一 & $H+$ & $H$ & H & H & Ht & H & H & H \\
\hline 12 & $3: 8$ & 우 & - & + & + & \pm & \pm & - & - & - & \pm & + & $H$ & Ht & HH & $\triangle$ & $H$ & HH & $H$ & Ht & $H$ & $H$ \\
\hline 13 & $3: 10$ & $\mathcal{B}$ & + & $H$ & $H$ & + & \pm & - & + & \pm & + & - & $H$ & $H$ & $\mathrm{Ht}$ & $H t$ & H & $H t$ & $\triangle$ & $\mathrm{H}$ & \# & $H$ \\
\hline 14 & $4: 9$ & ㅇ & $H$ & $H$ & - & + & + & - & - & - & + & - & H & H & $\mathrm{HH}$ & + & $\mathrm{HH}$ & $\triangle$ & $\Delta$ & $H$ & $H$ & $\mathrm{HH}$ \\
\hline 15 & $5: 6$ & $\hat{\jmath}$ & + & + & + & + & - & - & \pm & + & - & - & $H t$ & $\Delta$ & $H$ & $H$ & H & + & $H$ & $H$ & $H$ & $H$ \\
\hline
\end{tabular}




\section{5. 反応がない(一)}

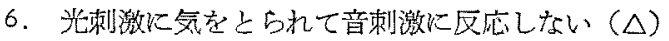

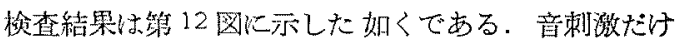
を結返えし与えた場合には，初めの1，2回は此較的明膫 に反応するが，間もなく反応がはつきりしなくなつたり 消失してしまう傾问が每り，この成績は既に荻場 報告しているのと添同様であつた。 こ机に反し音刺激

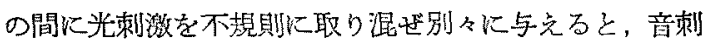

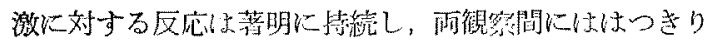
した差が存在する。

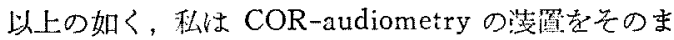
玉用いて，COR の原法とは異り，音刺激之光刺激を別

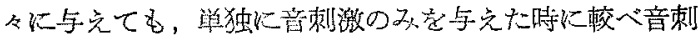
湤に対する反応が著明以認为られ且つ長く続くことを知 つたのであるが，この事军をどのように解釈したら良い か、この点について考察してみると，次の二つの要素が あるのではないかと思和机る。

1）光刺激は被檢児にとつて快浐な強力な刺湤と考光 られ，光刺激に上つて被梌児の心理状態は外间的となり 進儿で光刺激のみならず音刺游に詨して程極的に反应を 示しやすい状態上なる。

2）音刺激之光刺激の二つの刺激些取り混ぜることに よつて，一-喇激の反復に上る反応の減弱即ら「順 応」の現像か防止される，元来音刺激そのものも詮索反 射を花起せしぬる㞹的制激の一らなのであるから，剌激 の新焦さ老保たしめるよらな何等加の操作によつて反応

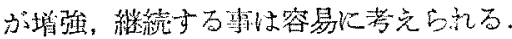

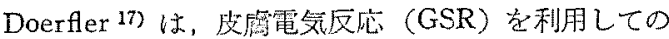
他覚的惪力湘定において，音刺激だけでは被梌者は音刺 激に対して関心を示さず反応が現れない例が少くないの

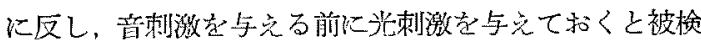
者の精神的祭張走促し音刺粕に対して明膫な反応を起し て，充分な闌值測定が可能ですることを報告している。

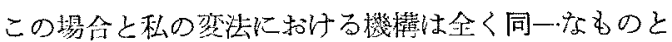

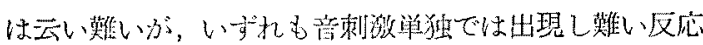
が，単に他の刺旅に伴初れることにより，明膫に出現し てくるといら点では共通であり舆味深い。

以上要するに，視觉刺湤を適当に泿して省刺激を与克 ると，特比条件形成を行わなくとも，はじめに繁条件反 応として出現した詮索反射（振り向き荤怔）が持続的に

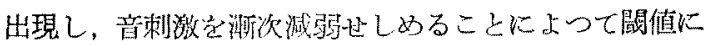

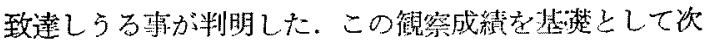
の如き測定方浩を權成しうる。

\section{第 III 章 变法の測定方法}

測定㳖置は原法と全く同様であるから省略する．被検 児も原法同椫凌置の前面約 $50 \mathrm{~cm}$ の所に坐らせる。

最初に被検児の䦨値上 40〜 50db と思われる $1000 \mathrm{cps}$ の純音を $3 \sim 4$ 秒間之光刺激を $3 \sim 4$ 秒間と各么独立 に不規則に左右上り与える. 刺激間の間隔は $2 \sim 3$ 秒と する. 音刺激と光刺激の回数の比率は $2: 1$ から1:1 位 の簛因とする，音刺激及び光刺激の与方方の 1 例を挙け゚ れば，先す右侧上り督(1)，次に左侧上り光(2)，右側上 り音 (3)，左侧上り音 (4)，右側上り光 (5)，左側上り

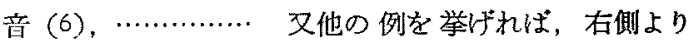
光(1)，左側より音 (2)，右側より音 (3)，左側より光 (4)，右側より音 (5)，左側より音 $(6) ， \cdots \cdots \cdots \cdots . .$. 等 である。このようにして音刺激に対して直ちに振り向く かどうかを及る。この際はつきりした反応があれば $5 \mathrm{db}$ ステップで音の強ざをげて行く。このようにして最小 の音の強さで反応を示した值を測定闎值とした，1000 cps が测定されたら他の周波数の测定に移る、このよう にして得られな値は兩耳の綜合揌力である。

第 IV 草 正常乳幼览の变法による測定成綪

耳疾患もなく，難㯖を訴えていない正常と思われる乳 幼睍 14 名について，末ず翌法に上り聴力を測定し，引 き続いて原法で測定して両者を比較してみた．被検児の 年令は 5 カ月から 3 年 7 カ月迄である. 検查時間がなが びいて，測定値に正確さのなくなるのを防ぐために雨者 とる $1000 \mathrm{cps}$ についてだ測定した．变法による閶值の

第 3 表 変法と原法による椡定值の比較

\begin{tabular}{|c|c|c|c|c|c|}
\hline 年 令 & 性 & 変 & 法 & 原 & 法 \\
\hline $0: 5$ & $\hat{\delta}$ & & 能 $\mathrm{d} b$ & & 能 $\mathrm{dl}$ \\
\hline $0: 12$ & $\delta$ & & ～能 & & 能 \\
\hline $1: 2$ & 甲 & \multicolumn{2}{|c|}{20} & \multicolumn{2}{|c|}{20} \\
\hline $1: 2$ & 우 & \multicolumn{2}{|r|}{10} & \multicolumn{2}{|r|}{10} \\
\hline $1: 5$ & $\delta$ & \multicolumn{2}{|r|}{30} & \multicolumn{2}{|r|}{25} \\
\hline 1. 7 & $\hat{\theta}$ & \multicolumn{2}{|r|}{20} & \multicolumn{2}{|r|}{20} \\
\hline $2: 2$ & 우 & \multirow[t]{5}{*}{60} & (不确実) & \multirow[t]{3}{*}{60} & (不確実) \\
\hline $2: 2$ & 우 & & 20 & & 20 \\
\hline $2: 4$ & 우 & & 20 & & 10 \\
\hline $2: 5$ & q & & 15 & \multicolumn{2}{|r|}{15} \\
\hline $2: 6$ & $\hat{\theta}$ & & 10 & \multicolumn{2}{|r|}{10} \\
\hline $2: 11$ & $f$ & \multicolumn{2}{|r|}{ （不确害） } & \multicolumn{2}{|r|}{ (不確実) } \\
\hline $2: 11$ & $\hat{\delta}$ & \multicolumn{2}{|r|}{10} & \multicolumn{2}{|r|}{ 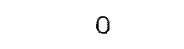 } \\
\hline $3: 7$ & $\hat{\delta}$ & \multicolumn{2}{|r|}{ ( } & \multicolumn{2}{|r|}{0} \\
\hline
\end{tabular}


決定は明らかに音刺激によつて振り向いた場合のみを陽 性とした。その成績は第3表に示した如くで，14例中 1 才未満の 2 例は雨法と乎施不能，2才 2 力月及び 2

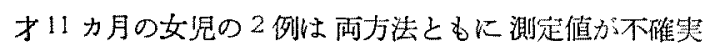
であるため，残りの10例について比較すると，10db及 び $5 \mathrm{db}$ の差のあるもの各々1例を除き8例では，雨法 による閶值は同一であるた。

\section{第 $\mathbf{V}$ 章 变法の臨床的応用}

前章に扎いて記载した如く，変法は1〜2才位の正常

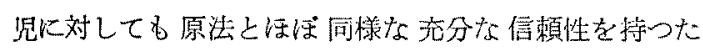
湘定方法になりらることがすかかった。更に翟法はその 測定方法に和いて条件形成を行わたい方法であり，徒 つて音剌激之光刺激力向の哂知の一致性を必要としな W.

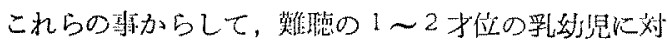

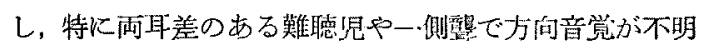

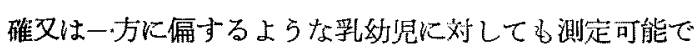
あり, 又との测定值に相当の信頼性があるであるうこと は充分推測でさる．侻し奏際に難悖览を湘定するに当つ

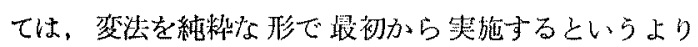

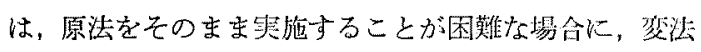

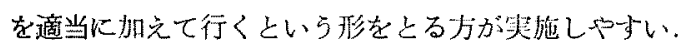

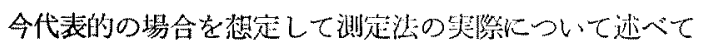
胃よう。

\section{1) 俩耳儿咕少差のある䭪合}

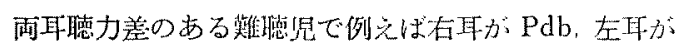
$Q \mathrm{db}$ とし $\mathrm{P}>\mathrm{Q}$ で， $\mathrm{Pdb}$ 以上の音に対しては方间点

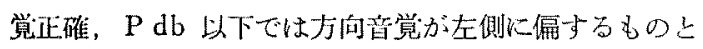

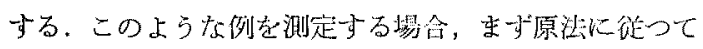

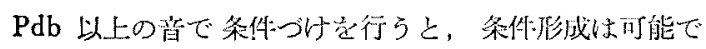

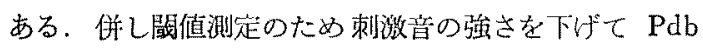
以下になると, 刺激音に対しては常に左侧力向を向くた め原法では湘定不可能となる。このよらな場合は右側よ

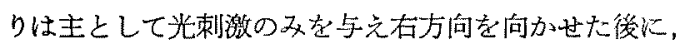
左側より音刺激を与光るといら变法的操作に切りかえ

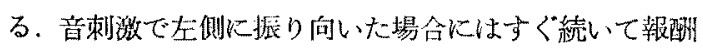

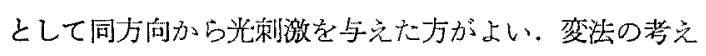
万からすればこの「皱㖄」は不要であるがここの方が結 果がよい.このよらにして意の強さを漸次弱めて關值湘 定する。

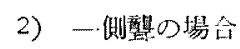

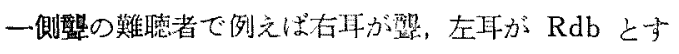
る、音はすべて左側より聞吕るものとする。このような
例の埸合は原法による条化形成は面可能である。そこで

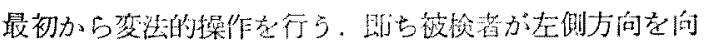

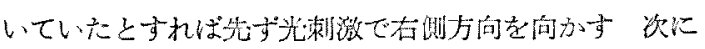

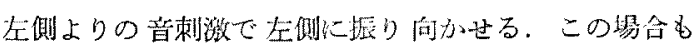

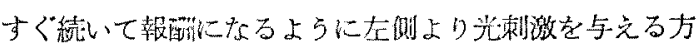
が結果がよい，次に北刺湤で右僋を向か子、次に左側よ

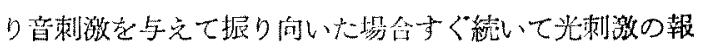

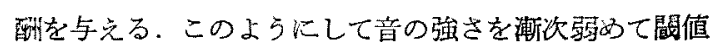
を測定する。

実際にはこのよらな単純な例ばかりではないから，原 法と変法の組合わせは证例によつて自然に種々の形をと るものと思われる。勾このようなう法を笑施するに当つ て注意すべきことは，既に符1編でのべた如く闒值に近

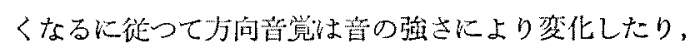
又同じ強さでもその㭙支の時で变化をさたすことが多い といら牙であつて，必ずし上にあげた例の如く明瞭な

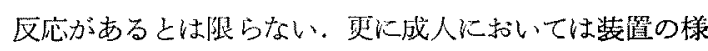

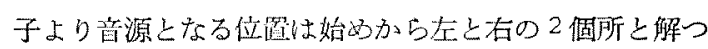

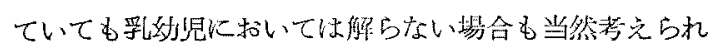

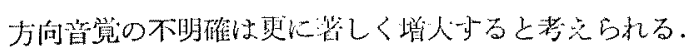

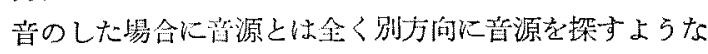
格好でキヨ口キヨ口見ますすといらような例多測定過程 に入つてくることもしばしばある゙，このよ5な埸合も

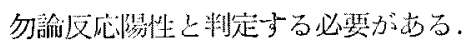

このようにCOR-audionetry の原法と变法上走適当

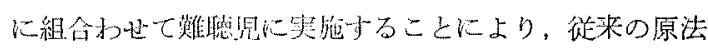

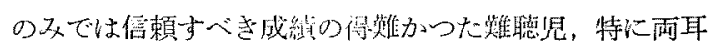

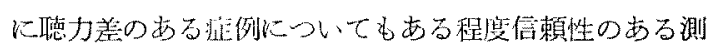

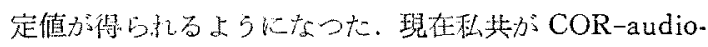

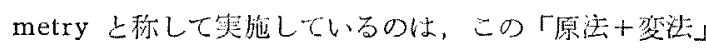

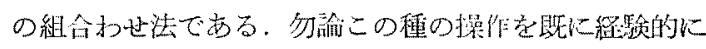

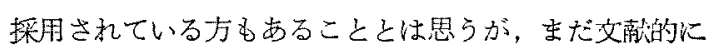
は報告されていないのでここに記载した次第である。

\section{第 VI章 結語}

1) COR-audiometry の溒置索用いて, COR の場合

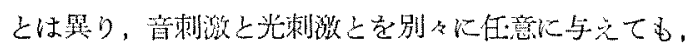

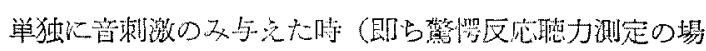

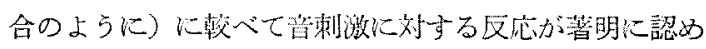
加長くつつく.

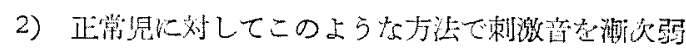

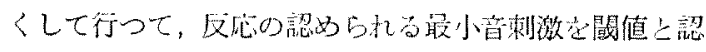
めると，この值㤬整の COR-audiometry の方法（原

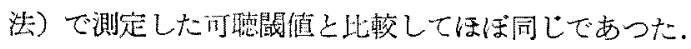


このような聴䦥測定法を便宜上 COR-audiometry の変 法とした。

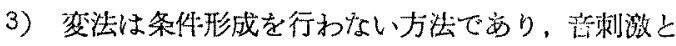
光刺湤方向の認知の一致性堂必要とせす，從つて方向音

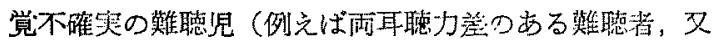

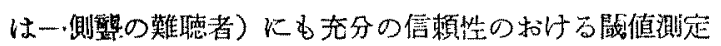

が可能であると推測した。

4) 原法と変法とを適当に組合わせて測定を実施する ことにより方向音覚不確実の難䎸児に対しても充分信頼 の指ける测定が可能となつた。 現在私共が COR-audiometry として实施しているのは，この「原法十变法」の 組合わと法である。

\section{第 3 編 COR-audiometry による難聴の測定}

\section{第I章 緒言}

前編に扎いて私は，COR-audiometry の装置伐用 してはいるが，原法と買なり条件形成走必要とせ收一つ の方法を COR-audiometry の变方として報告し，この 方法によつても閶値の澌定が充分可能ですると述へた。 この方法は原法の如き条件つけを行わないため, 高度の 難聴罗にむ応用でき，原法の笂施が困嚾ないしは不问能 の埸合にも有效であると教えるのであるが，既に述べた 如く，この変法は独立した测定法として利用するより も，既炕報告されている COR-audiometry の原法の中 に適当組合わ姑て使用すべきであり，著者が本編に打 いて COR-audiometry と称して使用している方法も，

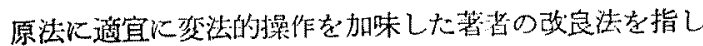
たものである。

本編に扣いては，著者の試みた測定方法の笑際に関与一 る2,3の工夫と，その方法に上り微察した難㯖児症例に つてて記载した。

\section{第 II 章 測定方法}

\section{(1) 淩監について}

荻場 4) 6指摘している如く，1才台，2才台で一部 可能例，不能例の一鼻大きな原因は检查に対する恐㤢心

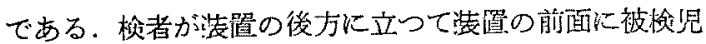
を坐らせ㭘查を行う時，しばしば被柃胃は众者の顔をみ つめる。このような場合検者の視線之被检見の視線とが 合うと，検查途中です急に恐怖心を懁き始めたり，そふ そわし始めて検查に応じてこない場合小゙ある，それ程で なくても闒値附近の弱音に対しては氛が散つて充分な反 応を示さなくなる塄合が多い，方向音覚の不明膫の難㴔 児の場合には正常紧に校ぺて検查が困難であり，充分に 被㭘胃の動作を観察して音剌激の与え方を工夫しながら 検査する必要がある，そこで装置の上方，検者の前面に カーテンを吊して被検児より検者が見壳ないようにし， 梌者侧を瞕くしてカーテンの一部にマヂックペーパーを はめ迈みこの視き空を通して検者は被㭘者の動作を観察
するように渻圈を谈善した。

\section{（2）検查前の難聴程萝の帵取}

摹聴児測定の際には江覾なり附添いの者に難㯖の程度 を予め聞いて括けばより㭘查が能率的に実施できる。 又 ぞちら側の耳がより恐いか㢃いが聞いて招くのも大切 のことである，前述した如く，だいたい閧値附近の羔刺 湤に対しては良耳側化音源があるように認知するから，

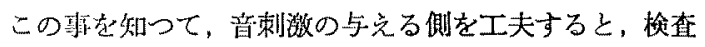
䀧間を短縮することができる。

(3) 䦭值決定に不磪実の湢を設けること

正常児と云之ども COR-audiometry に上る閔值の決 定は常に容易であるとは云えない，检查音を次第に弱め ていつてこれ以上反応がない場合，果して音を知覚しな いため反応がないのか，知筧しても弱音のため関心を示 さないのか，又方向音覚等が不確実のため充分な反応を 示さないのか迷う場合がしばしばある。

两耳聴力差のある難聴児の場合には，更に方向音覚 等の問題が著しく介入して何程度に閶値を決めて良いか 迷う場合が多い。この点は被㛟者の協力によつて閔值を 決定する大人の聴力倹查とは全く異る所である．そこで 例壳ば $\mathrm{Adb}$ 上上注はつぎりと反応があり， $\mathrm{Adb}$ 上り $\mathrm{Bdb}$ をでははつきりとした反応はないが聞えているら しいという場合，䦭值を一つ泆めようとすれば無理が 生したり検者の主観が入つたりするので，Adb よりB

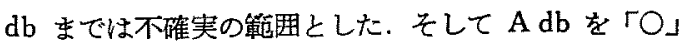
で記载し， $\mathrm{Adb} よ り \mathrm{Bdb}$ までを「け」の附号で記载

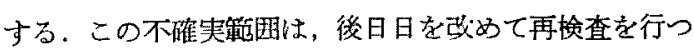
て是正してゆく，むつとも初回検查に打いて不確実範国 が 20〜30db にも達する上5な者は，再検查に括いて も，又検者を代えて榆查してもだいたい同じょうな結果 が得られる場合が多い。

(4) 测定の夹施

測定は COR-audiometry の原法に変法的操作を適宜 に加えて実施した，その詳細については前編に記载して 
日耳武居＝条件洤索反射聴力測定法（COR-audiometry）の改良に関与る研究（第3編）66一1379

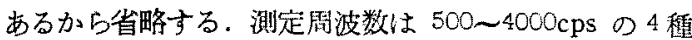

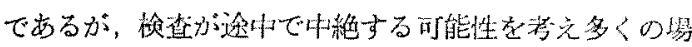
合 $1000,4000,500,2000 \mathrm{cps}$ の順に湘定した。

\section{第 III 章 観祭症例}

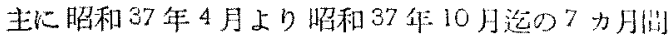

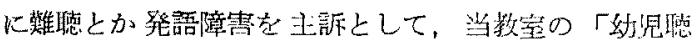

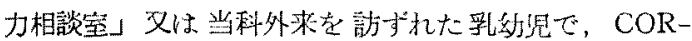
audiometry を拝施した 60 例の中上り，両耳差のある 難㯖見や，信頼性の間題を考学るのに適当と思方れる12

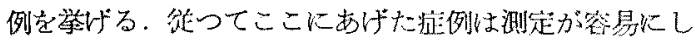

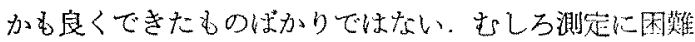

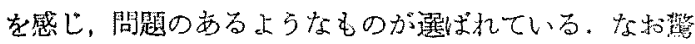

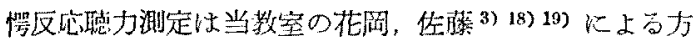

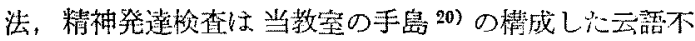
用検查法によつた。

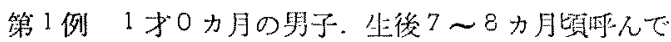

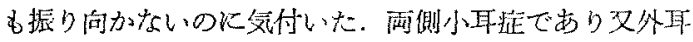

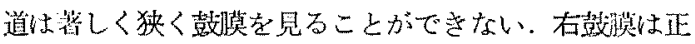

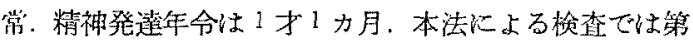
13 図の如く $1000 \mathrm{cps}$ では $60 \mathrm{db}, 4000 \mathrm{cps}$ では $95 \mathrm{db}$ で

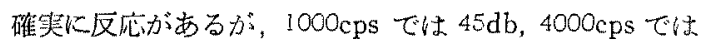
$70 \mathrm{db}$ まで不確舁ではあるが反応があるように思う。閶

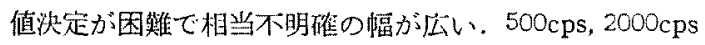

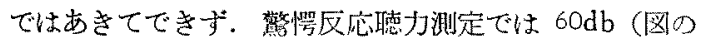
左端にーで記载）で本法とほぼー致している.

第 13 㘣

第1 例( 1 于0 月 月

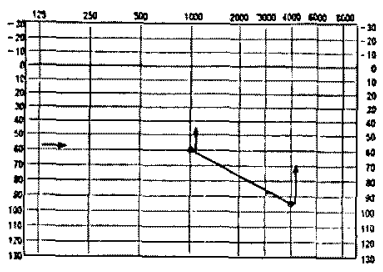

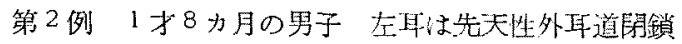

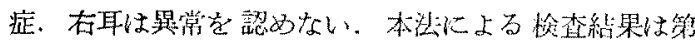

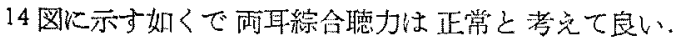

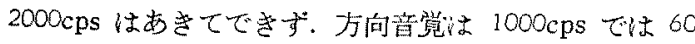

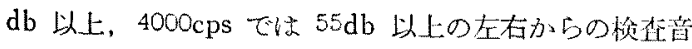

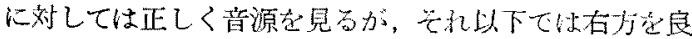
く見るので，左耳の嘅值が多分て心附近にあるのだらう と推測せしめる。

第3 例 3 才 9 力月の女子. 云語障彗儿て来院。四の 云ら事が一番良く聞无るらしいとのことで特別難㯖には 気付かなかったとのこと. 生後 9 力月頃風邪て $39.6^{\circ} \mathrm{C}$
第 14 图

第二倒( 1 才 8 力

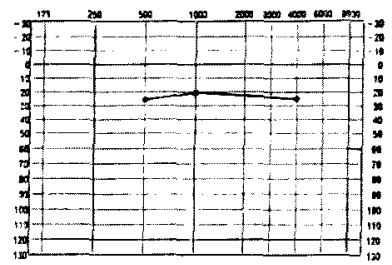

第 15 図

籍 3 例( 3 才开月)

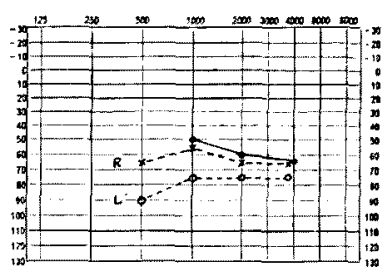

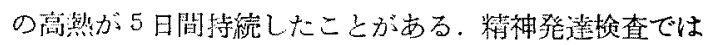

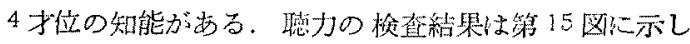

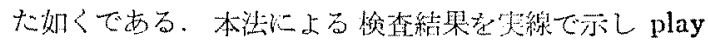

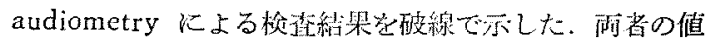
はよく一致している。な标 play audiometryによる简

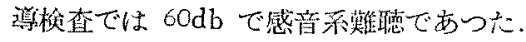

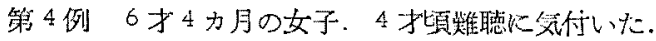

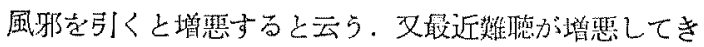
たとのこと、聴力榆榃の絬果は第16 図に示した。本法

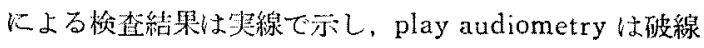

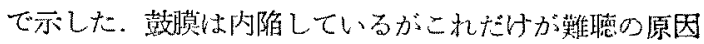

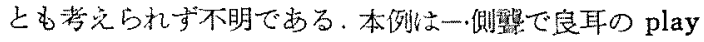

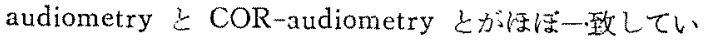
る例である。

\section{第 16 図}

第 4 例 (6才4 月 4 月)

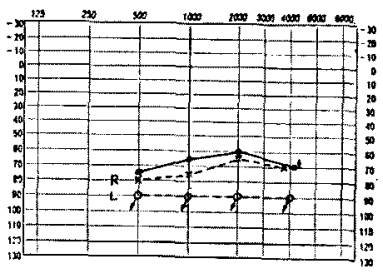

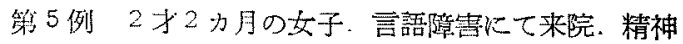

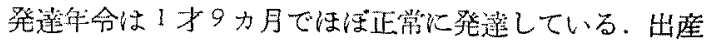
时仮死状热であつたとのこと，鼓膜所見には翼常を認め

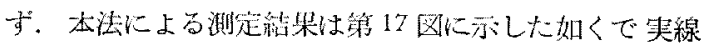

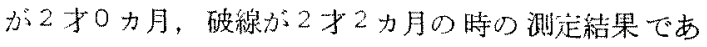

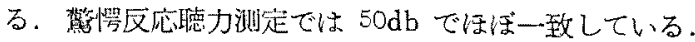
本例は 2 力月和いて検查しているのであるが 2 回とも閖

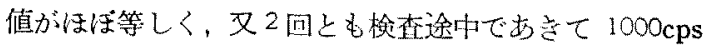
上 $4000 \mathrm{cps}$ の 2 力所しか检査できなからた例である。 
第 17 図

第 5 例 $(2 \nmid 2$ 力 2 )

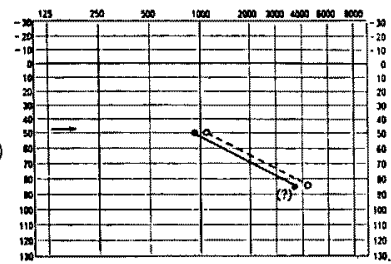

第6例 $2 才 4$ カ月の女子. 言語障害が尘訴で来院. 一語文しか云えない，半年位前からかけのわからら歌を 歌ら。本法による検查結果を第18 図に示した。「○」は 初回检査であり破線は 4 力月後の再检查結果である。初 回検查ではすぐあきてきて $1000 \mathrm{cps}$ しか測定できず， 又再検疽でも検查を恐しがらて充分に測定できなかつた が，これ以上良い上うに思えた。精神発逢年令は 2 才 1 カ月である。言語障害の原因となる 難聴は涄えられな W.

第 18 図

第 6 例 ( 2 才 4 力月)

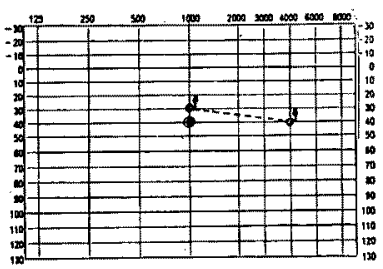

第 7 例 3 才 5 力月の男子 生後 2 才 7 月に 5 米位 の石や木株等のある所へさかさまに落ちた。それが原因 と考えられるがその頃より難聴となつた，当洔に較べる と最近はやや良くなつてきているょらに思らとのこと。 精神発達年令は 3 才 10 力月. play audiometry は難㯖 のため検査の意図が理解できず不能．本法による検查結 果は第 19 図以示した如くである。垁線は 3 才 5 力月の 時であり，破線は 3 才 7 月の時である。両検查とも閍 值附近になると音刺激を与えるたびごとにキヨロキヨロ 周囲赈り向き音源がわからないようだ。不確実の愊む やや広く，2 カ月後の検査ではやや閔值が下降している のが認められる。

第 8例 言語障害で来院. 単語は大部云えるが不明瞭

第 19 図

第 7 例( 3 才 5 力月)

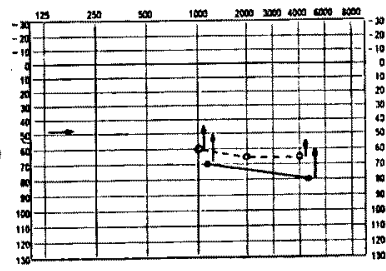

第 20 図

第 8 例( $6 才 2$ 力月)

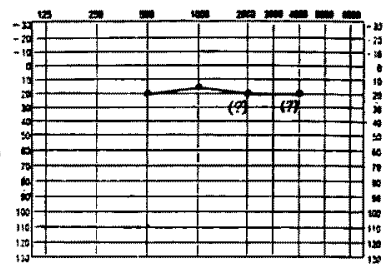

であり二語交はできないとのこと. play audiometryは 不能. 精神発達年令は 2 才八月. 本法に上る検查結果

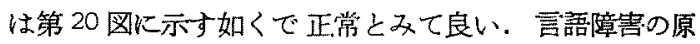
因となる難㯖は考克ら机ない。

第9例 6 才 2 カ月の文子 3 年前より呼んでも振り 向かないので難聴があるのではないかと思っていた，最 初の言語を出した時期は $4 \sim 5$ 北頁である. $7 \sim 8$ 力月 前から云語の数が增してきた，知能検査では検查が充分 にできず文途中であさてしまう，精神薄弱であり play audiometry も不能である. 本法による检查結果は第 21 図に示した如く 40〜55dbである．警愕反応聴力測定は

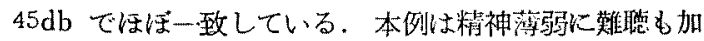
つた例である。

\section{第 21 図}

第 9 例(6才2 招月)

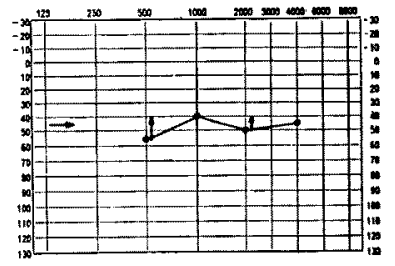

第 10 例 2 才 6 力月の男于. 2 力月前に難聴汇気付 く，気付いた頃より增憖するように感ずる，原因は不明 である、精神発逢年令は 2 才 1 力月である。 2 人の検者 による本法の検查結果は第 22 図の如くで， ほぼー致し ている、両検盉時とも，落着きがなく䧕值決定が不明瞭 であつた。

第 11 例 1 才 7 カ月の女子 難衈と言語障害を主訴 として来院. 生後 4 力月頃敬血症に檴り $40^{\circ} \mathrm{C}$ の高熱が 1 週間続いた。 その際ストマイも使用している. 大声で

第 22 図

第10例 $(2$ 才 6 力)

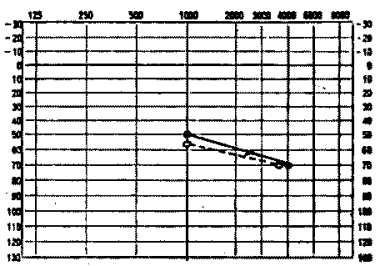


第 23 图

第11例( 1 丮7 出)

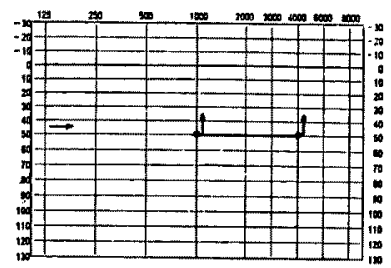

呼んだ時稀江振り向く時もあると云う，精神発達年令は 1 才九月. 本法に上る枪查結果は第 23 図に示した加

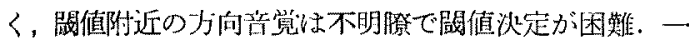
般に左方に良く向く，右耳儿校べて左耳が良いのではな いかと思われる， $1000 \mathrm{cps}, 4000 \mathrm{cps}$ とも50dbで確䇛に

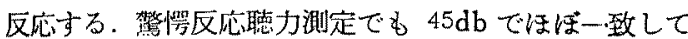
いる.

第 12 例 1 才 5 力月の女子. 生後音に対して区応を 示したが 3 力頃結核性脳膜炎に覆りストマイ，カナマ イシンを大量に使用した。生後 7 力月頃難㯖に 気付い た．本法による検查結果は第 24 図に示したが，第 1 回

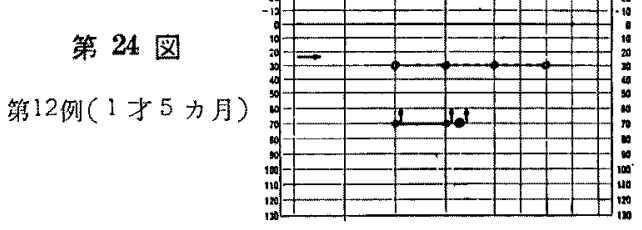

目は生後 10 力月の封で「○」で示し，第 2 回目は11力 月で实線で示し，第3回日は1才8カ月で破線で示し

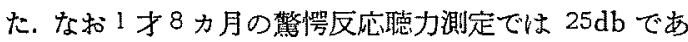
つた. 本例は 9 カ月間に著しく聴力が改善されてきた経 過を示す例である。

\section{第 IV 章 綜 括}

以上我々が実施している COR-audiometry の見段階 とそれによる測定例の実際について述べてきたが，今こ の12症例について簡単に綜括して見ると，一般に難聴 児に扣いては常に方向音覚の開題が介入する場合を予測 する必要があるので，閩值決定は正常児に較べて慎重で なければならず，従つて検査時間が長くなり途中であき るようになる。妇測定方法において原法よりも变法が主 体をなす場合には原法のみの場合に比して一定時間内の 反応回数が少なくなり，従つて 4 周波数の測定が困難に なる場合が多い，併し一万 play audiometry の適令期 でありながら，中等度爻は高度難聴で検査の 意図が被 㭘児に理解されずそのため play audiometry が不可能
の例や，又5〜6才になつても精神薄弱や翼常性格で play audiometry が困難か不可能の例で，本法で測定

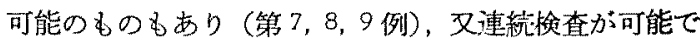
聴力消長の経過を䚁察できた例（第 12 例）むあつた。 又知能障害がなくても不確奏の愊が正常児に較へて著し く大きく 20〜30db Kむ達する例（第 1，7，11 例）があ り，難㯖の性質，両耳聴力差等之何等かの関係があるか ぞらか，椮討を要するものと考觉られる。

鈴木及び荻場が COR-audiometry の原法を曼初に発

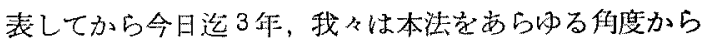
众討し，又その改良を計つてきたが，朴法は今日に至つ てもなお決して完成された方法ではなく，そのなか炕多 くの久点と問題を内蔵しているものであることは否定で きない，本論文に拈いて取上げてきたものも正にその一 つであり，こ机伩してはある程度の解決を与克得たす のと思5が，残された問䟎の多くについては，今後謙虚 な気持と着实な努力によつて解決して行か极ばならぬる のと考光る次第である。

\section{第 V章 結 語}

第 2 編において報告した COR-audiometry の改良法 を便用し, 昭和 37 年 4 月上り 10 月迄の 7 力月間に約 60 例の難㯖児の 聴力測定を奏施したが，その中より 12 症

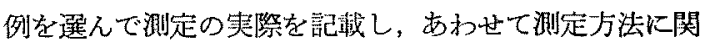
する若干の土たついて述べた。

\section{參考文献}

1) Suzuki, T. and Ogiba, Y: A technique of pure tone audiometry for children under three years of age. Conditioned orientation reflex (C.O. R.) audiometry, Rev. Laryng., 81, 33, 1960. 2)

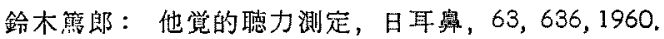

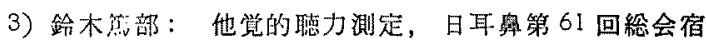

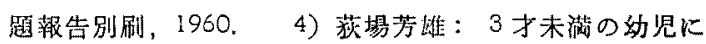

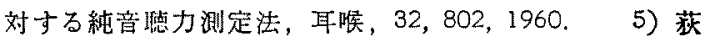
場芳焳：条件詮索反射聴力测定法 (C.O.R.--audiometry）の桱討，日耳鼻，64，855，1961。 6）鈴木篤郎： 乳幼児の㯖力測定，小胃科，2，31，1961，7）Suzuki， T. and Ogiba, Y.: Conditioned orientation reflex audiometry, Arch. Otol., 74, 192, $1961 . \quad 8$ 8) 荻場芳 崔：1才未㶓児の純音聴力测定，耳喉，34，277，1962. 9) 武居哲也. 条件弪索反射聴力测定 (COR-audiometry）に上る乳奻児の正常聴力について，日耳囱，65， 1106, 1962.110$)$ Trenque, P. et Lafon, J.C.: Les troubles de l'audition chez lénfant et leur mesure, 
La med. Infantie, Nov. 1961, No. 9, 29. 11) Schröder, K. et Relke, w.: Probleme der Kinder Kinderaudiometrie-dargestellt an der Methode des bedingten Orientierungs reflex es $Z$. Laryng. Rhin., 41，682，1962. 12）大内代, 武山貢次, 立水孝, 䀡

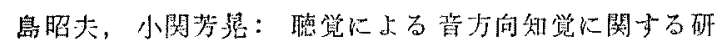

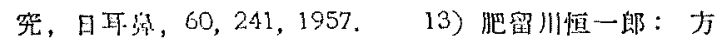
向音觉の研究，可奥臨，52，642，1959。114）立木考，

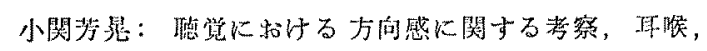
27. 239, 1955. 15) Erving, I.R. and Ewing, A.W. $G$.: The ascertainment of deafness in infancy and early childhood, J. Laryng., 59, 309, $1944 . \quad 16)$ 村 岛昌一：音源の方向による㴔力变動に就いて，日耳率，
$62,704,1959$

17) Doerfler, L.G.: Neurophysiological clues to andiory acuity, J. Speech Hear. Dis., 13,227, 1948.

18）花岡藮：乳纤児聴力湘定法

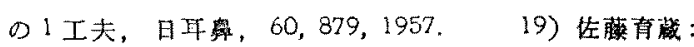

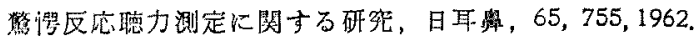

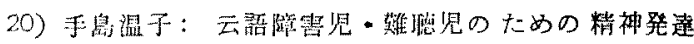
柃查，日耳瓜，65,989，1962.

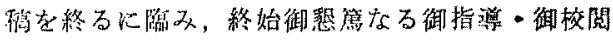
を晹つた恩師鉿木篗郎教授亚びに整々御助云下さつ

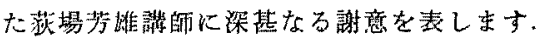

（原微到管 $=$ 昭和 38，6，4 日）

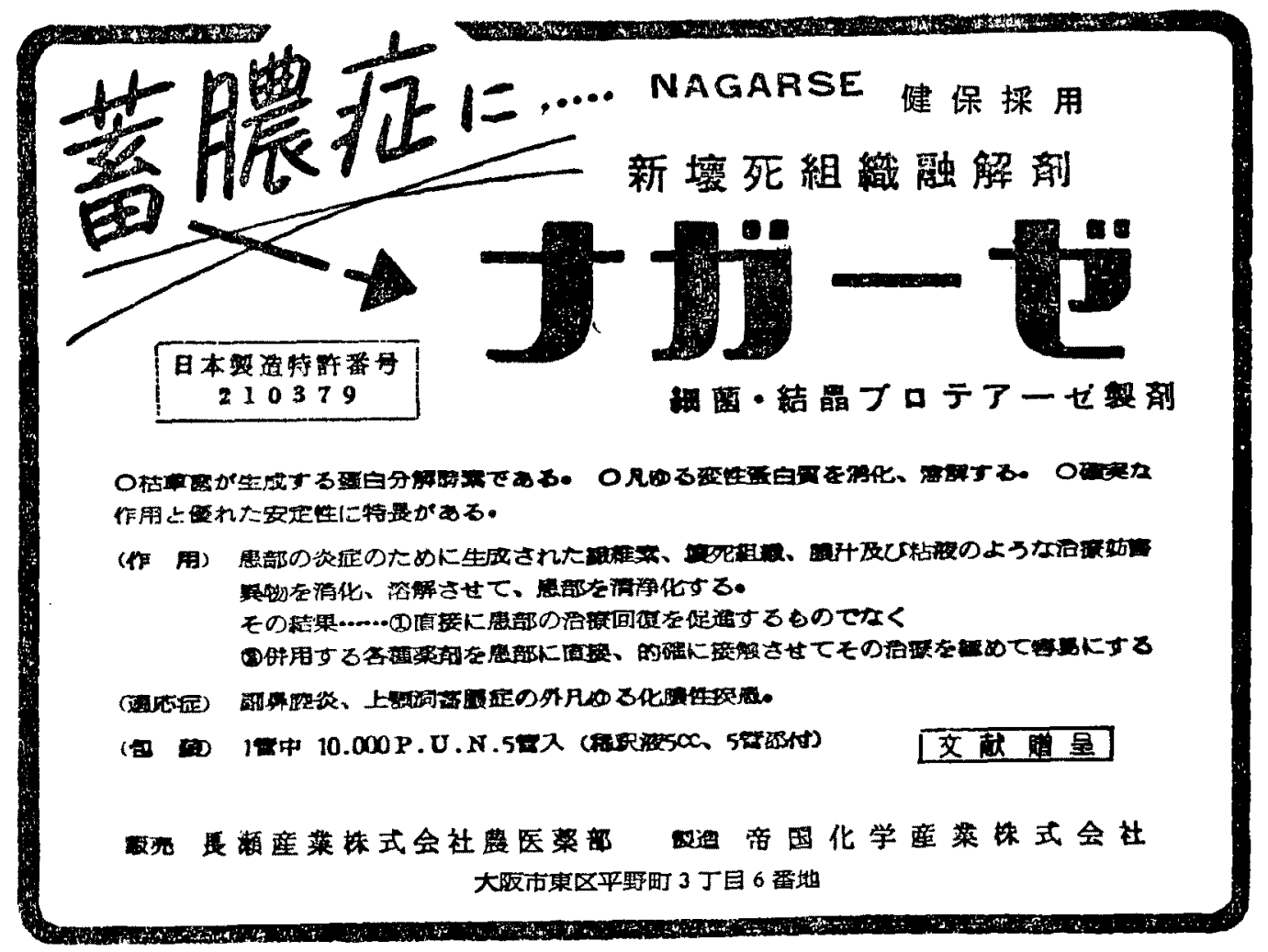

